Portland State University

PDXScholar

1979

\title{
The Federal Writers' Project in Oregon, 1935-1942 : a case study
}

Thomas James Ptacek

Portland State University

Follow this and additional works at: https://pdxscholar.library.pdx.edu/open_access_etds

Part of the United States History Commons

Let us know how access to this document benefits you.

\section{Recommended Citation}

Ptacek, Thomas James, "The Federal Writers' Project in Oregon, 1935-1942 : a case study" (1979). Dissertations and Theses. Paper 2895.

https://doi.org/10.15760/etd.2889

This Thesis is brought to you for free and open access. It has been accepted for inclusion in Dissertations and Theses by an authorized administrator of PDXScholar. Please contact us if we can make this document more accessible: pdxscholar@pdx.edu. 
AN ABSTRACT OF THE THESIS OF Thomas James Ptacek for the Master of Arts in History presented February 14, 1979.

Title: The Federal Writers' Project in Oregon, 1935-1942: A Case Study. APPROVED BY MEMBERS OF THE THESIS COMMITTEE:
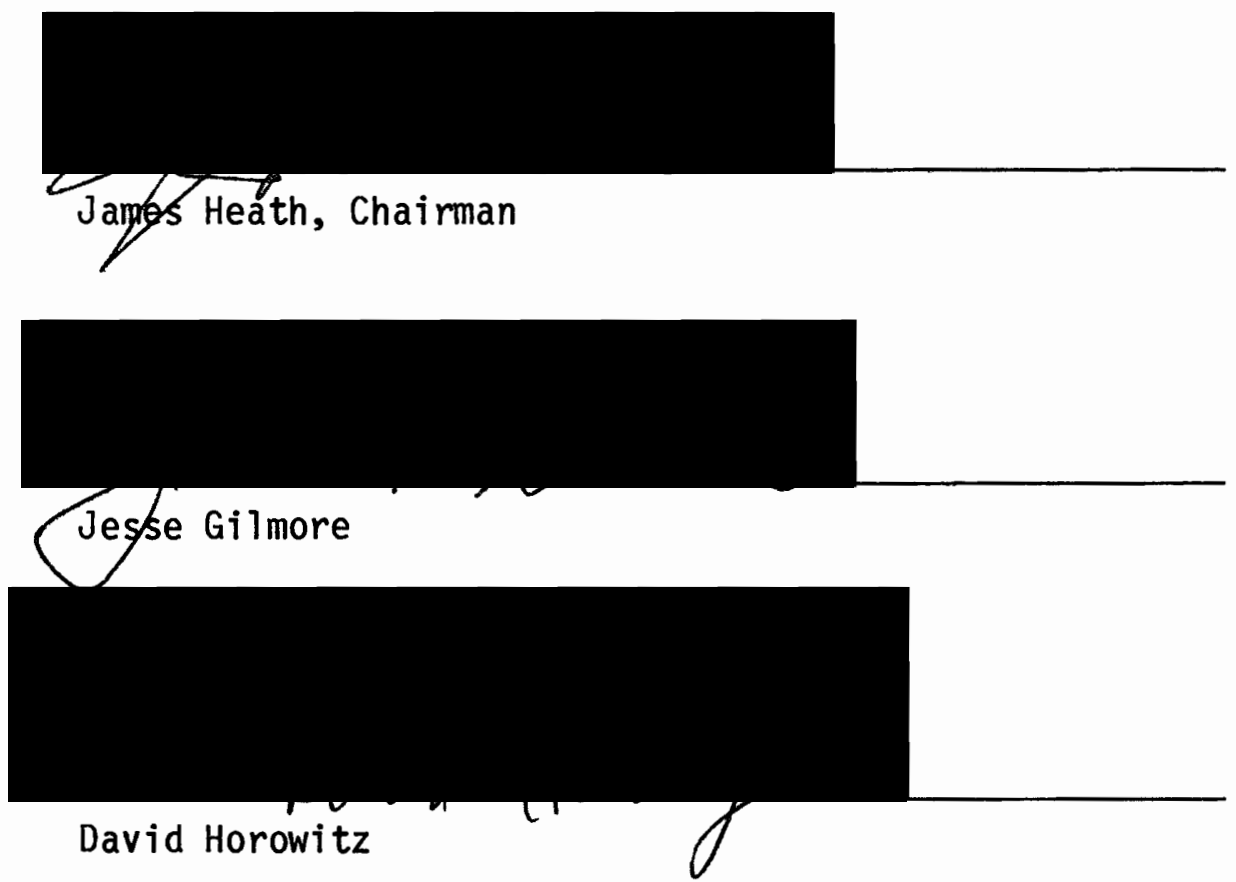

The Federal Writers'. Project was created in 1935 as part of the Works Progress Administration. This project represented an example of the highest evolution of work relief philosophy of the New Deal during the depression of the 1930's. Unlike previous work relief programs, the Federal Writers' Project sought to employ people in their chosen profession. This task was accomplished with the establishment 
of writers' projects in each state under the guidance of a national office. The major goal of these individual projects was to research, write and edit a state guidebook. This current study surveys previous research on this program and looks at the program nationally before it concentrates on the Oregon Writers' Project as an example of this type of work relief.

Oregon's major goal in implementing the program was to employ as many unemployed writers as possible. The project was hindered somewhat in doing this because of the lack of "good" writers on relief and the national office's failure to establish a definition of a writer. This lack of definition allowed any would-be author to apply for a job. In spite of these problems Oregon managed to put together a fairly competent staff including many unemployed college professors, newspaperpersons and locally published writers. Those who were not qualified to write were kept busy working on necessary research.

Oregon's major problems occurred in the administration of the program. Alfred Powers, first State Director of the project, generated much enthusiasm for the project but his actions eventually forced his resignation. He was criticized for lack of attention to his job, for spending too much of the project's time on unauthorized publications, and for nearly precipitating a strike by the writers. T. J. Edmonds, Powers' successor, was an excellent administrator though he also allowed the project to spend too much time on unauthorized publications. These publications were often of poor quality. As with the guide books, they were designed to avoid controversy. Today these written works are dated and serve little useful purpose. The truly 
worthwhile materials of the project, such as the oral histories and research notes, remain unused in the State Archives in Salem, Oregon. Administratively, the largest failure occurred with the poor relations between the national editors in Washington, D.C. and the writers in Oregon. In many cases Oregon was at fault in using poor writers, verbose style, inaccurate or incomplete materials, and creating delays in sending copy to Washington. The national editors, on the other hand, could equally be faulted for delays in editing materials, confusing and constantly changing guidelines and unnecessarily harsh criticisms of Oregon writers.

In conclusion, this study takes exception with some of the other works on the Federal Writers' Project. First, this study argues that the Oregon Writers' Project cannot be used as a measurement for the effectiveness of government subsidy of the arts. The people who ran the program never claimed to be supporting art but to be supporting unemployed writers. In fact, the administrators tried to discourage any freedom or flexibility which would have provided a climate for the writer to flourish in the artistic sense. With this recognition in mind, one may not validly use the Writers' Project as a tool for accurate measurement of governmental subsidization of art.

This study also takes major exception to a previous work presented on the Federal Writers' Project in the Pacific Northwest. That study argued that a project was unnecessary in the Pacific Northwest due to the area's "literary and intellectual backwardness." In Oregon the program certainly had its problems, but the project was generally successfur in meeting the major intent of the program--employing the 
unemployed in their self-selected profession. This program was not only useful but also humane; furthermore, it managed to preserve important history and the skills of people out of work in a time of severe depression. 
THE FEDERAL WRITERS' PROJECT IN OREGON,

1935-1942: A CASE STUDY

by

THOMAS JAMES PTACEK

A thesis submitted in partial fulfillment of the requirements for the degree of

MASTER OF ARTS

in

HISTORY

Portland State University

1979 
TO THE OFFICE OF GRADUATE STUDIES AND RESEARCH:

The members of the Committee approve the thesis of Thomas James Ptacek presented February 14, 1979.

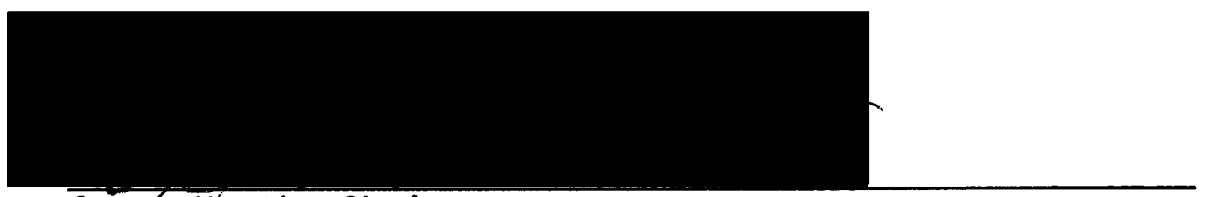

James Heath, Chairman

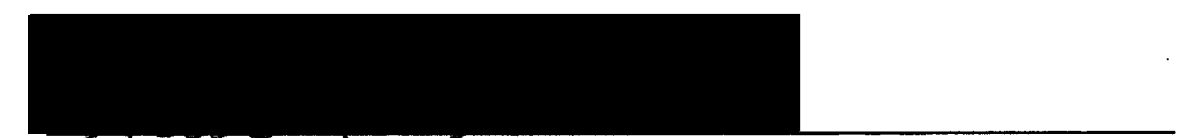

Jes\$e Gilmore

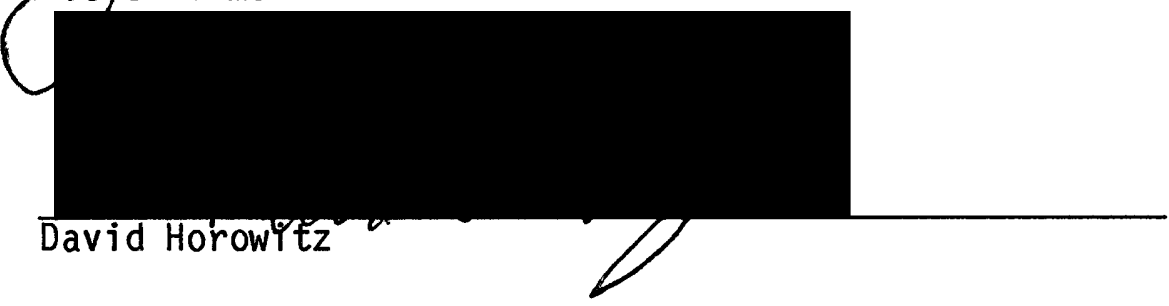

APPROVED:

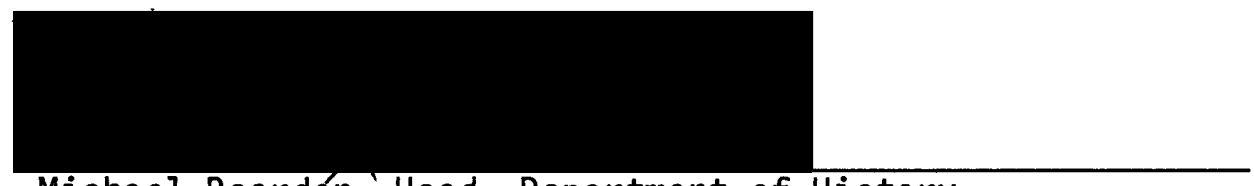

Michael Reardón, Head, Department of History

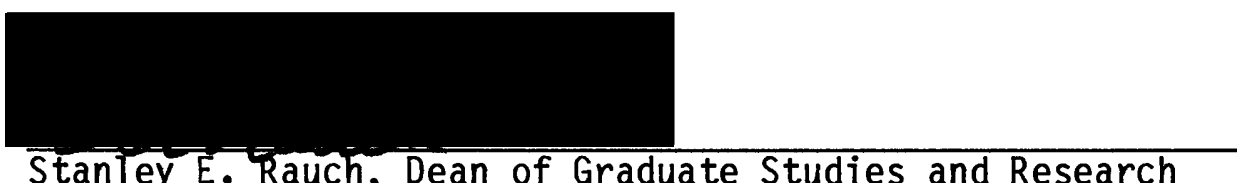




\section{TABLE OF CONTENTS}

\section{PAGE}

\section{CHAPTER}

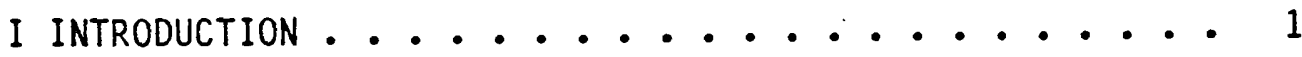

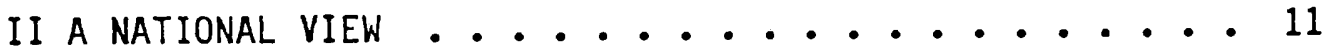

III A BEGINNING: OREGON $1935-1937 \ldots \ldots . . . . . . .44$

IV OREGON: $1937-1942 \ldots \ldots \ldots \ldots$

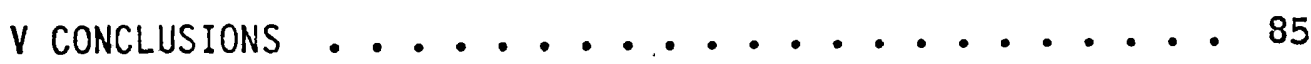

BIBLIOGRAPHY ..................... 98 


\section{CHAPTER I}

\section{INTRODUCTION}

In an article on the role of the arts and the public, Saul Bellow, one of America's most acclaimed novelists, discussed meeting his first writer in the late $1920^{\prime} \mathrm{s}$. This writer was an elderly Chicago neighbor who turned out "pulp stories." The man was acutely aware that as a writer his lifestyle was different from his neighbors who spent their days away from home working in business and industry. He told Bellow that "people see me hanging around and they think I'm sick or loafing. But I'm not a loafer, I'm a writer." From this conversation Bellow learned early in his career the "obvious" about being a writer in America. Bellow stated:

one could not write in the attic on an old typewriter no longer fit for business correspondence, looking down into streets deserted by all decent people, by men earning their bread, as men should, by the sweat of their brows. Not long before, Coolidge had told us through his New England nose that the business of America was business. We might despise him for saying such a thing but no one could prove that the proposition was false. We were living, in those days as, for the most part, we still live in vast industrial compounds. American cities, evep New York, are formed by the necessities of business and work.

Saul Bellow was attempting to define the role of the writer in a business oriented society. Bellow's sensitivity to this issue was heightened because he became a writer during the depression of the 1930's. Popular American stereotypes usually pictured writers and artists as impoverished and struggling. During the midst of the depression of 
the $1930^{\prime}$ 's this stereotype became painfully true for many writers in the United States. Book sales dropped, magazines and newspapers lost advertising and were forced to cut staff, and schools suffered decreasing enrollments. The writer, often considered a luxury to the practical, seemed wasteful and superfluous in the midst of an economic catastrophe.

This study will examine an unusual experiment which dealt with a practical literary movement during the midst of the 1930 's depression-the Oregon Federal Writers' Project. The project concentrated its energies not so much on producing the written word but on supporting the source of the word, the writer. The Federal Writers' Project ${ }^{2}$, a part of the Works Progress Administration, ${ }^{3}$ was created in 1935 and for the next seven years provided jobs for unemployed writers in a depressed economy. 4

Little remains of the Oregon Writers' Project. The Archives of the Oregon State Library in Salem became the burial ground for the bulk of the existing original papers, unpublished manuscripts, letters, and other ephemera of the Project. This material, along with the administrative papers on microfilm, a few published books, and the memories of some of the former staff members of the project ${ }^{5}$ are what is left of Oregon's role in the American government's most ambitious sponsorship of the arts in its two-hundred year history. ${ }^{6}$ Elsewhere in the nation, as in Oregon, the legacy of the Federal Writers' Project has been relegated to librarians, archivists, and the dusty memories of people who were affected by the project. ${ }^{7}$ Yet the Federal Writers' Project whether a success or failure, deserves to be examined by historians for at least two important reasons. 
First, the Writers' Project came to represent the highest progression of the relief programs of the New Deal. Along with the music, art, and theater projects, the Federal Writers' Project was created by executive order in 1935 and constituted Federal Project Number One of the Works Progress Administration. The Writers' Project lasted from late 1935 to early $1943^{8}$ and at its peak in 1936 employed over seven thousand people. ${ }^{9}$ This project, along with the other arts projects, was the government's most ambitious attempt at employing people classified as white collar workers in their chosen fields. One student of the program explained the importance of the Writers' Project as work relief with the observation that while the Project did not bring about "a renaissance in American literature," the program was significant because it represented the farthest evolution of the New Deal in self centered work relief. Prior to 1935, relief programs had merely attempted to provide jobs, but with Federal Project Number One the government made a commitment to maintain skills and morale by employing professionals in their chosen fields. ${ }^{10}$ The Writers' Project constituted an example of the "ideal" work relief program of the New Deal. It is useful, then, to examine the Writers' Project and its functions, particularly its administrative functions, as a means of judging its performance as a viable white collar work relief program.

A second reason for examination of the Project is that the Writers' Project, along with the other arts projects, marked the first time in American history that the federal government appeared to undertake a large scale subsidy of the arts. In the early nineteenth century, the government had toyed with the idea of using public funds for the 
arts, but little became of this idea. Literary and artistic endeavors were neglected until after the Civil War, when wealthy capitalists in an effort to "get cultured," began pouring money into symphony orchestras, museums, opera, libraries, and various other cultural outlets. Today most of America's cultural institutions are still dependent upon such contributions by the private sector and private foundations. In many cases this has hindered the growth of the arts in this country, because they are dependent upon the contributions and hence, the whims of the weal thy. The arts must also attempt to provide programs of entertainment aimed at playing to a full house.

The 1930's showed just how vulnerable the arts were to economic cycles. Overnight, money for these programs dried up because their main backers, the wealthy, could no longer afford to support them. One historian of the 1930 's commented:

Private philanthropy abruptly halted as weal thy men shifted their dwindling fortunes into more practical uses, and as it did so theaters and operas closed their doors, symphonies gave up the struggle and artists and writers begged for bread on the street. ${ }^{11}$ The paucity of funding for the arts left the government with one of two choices: it could either forget about the arts during the economic crisis and run the risk of a near-cultureless society; or, it could step in and provide financial aid to the arts. Fortunately for many painters, musicians, and writers the government chose the latter course. One might wonder, however, how fortunate these writers and other artists were. Surely these people had been granted modest economic security with the right to work in their chosen fields, but at what price? Can a writer, painter, or musician have their artistic freedom 
and receive a check from the government; or is the artist, in his/her quest for free expression an anathema to the bureaucracy and rigidity of an uncreative government? And were those who accepted government subsidy persons of genuine creative talent or rather individuals who wished to be artists, musicians, or writers but actually lacked the skills to achieve their goals?

Others have tried to answer these questions in dealing with the Federal Writers' Project. The most recent work on the Writers' Project, The Dream and the Deal: The Federal Writer's Project, (1935-1943) was written by a former national staff member of the Project, Jerre Mangione. In assessing the program, Mangione failed to give an incisive critical analysis of the Project. Instead he suggested that the experiment offered no clear answer as to the wisdom of governmental subsidy of the arts except for the fact that it did achieve a few positive accomplishments:

- . it was a freak enterprise, a strange creature of the Depression created by a special breed of men and women known as New Dealers whose motive was more political than cultural. The hope that a writers' project could somehow enhance the nation's culture was a fragile one in the minds of those who fathered it. Before the Project began fo show what it could do, Harry Hopkins [WPA Chief Administrator] considered it "fantastic" for the government to dare play the role of author. And fantastic it was; but the writers and the non-writers on the Project managed to play their role well. 13 they produced more good books than anyone dreamed they could. 13

Concurring with Mangione, academicians such as Carl Degler, Paul Conkin, William E. Leuchtenberg, and Alfred Kazin all have described the positive accomplishments of the program and its successes. ${ }^{14}$ 
Degler agreed with the editors of Fortune magazine that the arts program of the New Deal created "a sort of cultural revolution." He suggested that perhaps the most important accomplishment of the program was the preservation of the "precious skills" of thousands of painters, writers, and musicians who found employment in the program. 15

Some high praise of the Federal Writers' Project came from those who were employed on the Project. Saul Bellow, once an employee of the Illinois Writers' Project, reminisced:

We adored the Project, all of us. This was in the days before gratitude became obsolete. We had never expected anyone to have any use whatsoever for us. With no grand illusions about Roosevelt and Harry Hopkins, I believe they behaved decently and imaginatively for pgen without culture--which is what politicians necessarily are.

Another author and former director of the Idaho Writers' Project, Vardis Fisher, gave only grudging approval to the program. Fisher observed that the price of the program was perhaps too high for the amount of work accomplished, "but at the same time it was an era of depression when they were putting people to work. I think it was a magnanimous gesture on the part of the government." 17

Not all surveys of the Project have been as tolerant as even Fisher's half-hearted approval. Mable S. Ulrich, former director of the Minnesota Writers' Project, was critical of the program as early as 1939. UTrich criticized the national writers' office for its stifling and confusing instructions. She also lamented the necessity to hire incompetent writers, which led her along with others to wonder whether, or not, the Writer's Project, "while conceivably the best possible [plan] for a six months' emergency, has proved itself sound for indefinite continuance; in short, we believe that a definite modification is now in 
order."18 Echoing UTrich, another former state director of the Project, Ray Billington of Massachusetts, also questioned the effectiveness of the program as a cultural venture. Billington pointed out that among other problems, the project "perpetuated mediocrity by coddling persons of limited talents," allowed individual talents to be "subordinated" to collective research and writing, and suffered political interference which was ever present and which hindered writers from completing many of their undertakings. Billington also complained about the lack of proper guidance from the national office and the problems that writers had with the censorship of their materials. ${ }^{19}$

Perhaps the harshest criticism of the program to date came from Ronald Taber's Ph.D. dissertation, The Federal Writers' Project in the Pacific Northwest. According to Taber, the problems faced by the state projects in the Pacific Northwest were almost overwhelming. For example the national office and the state projects were never able to establish a uniform policy "which combined artistic skill and government sponsorship." Taber, like Billington, also noted the intensive political interference that constantly hindered the projects. This was particularly true in the state of Washington where the Project was a political football and closed without a single publication to its credit. Lack of competence among the staff, which made it almost impossible to finish project undertakings, was another failure of the program in the northwest. 20 Taber harshly concluded that

the Pacific Northwest Writers' Project failed to establish an effective precedent for government support of the writer. It suggests, further, that given the literary and intellectual backwardness of the Pacific Northwest in the 1930's therg should not have been a Federal Writers' Project in that region. 
The present study supplements Taber's survey of the Project in the Pacific Northwest by concentrating exclusively on the Federal Writers' Project in Oregon. By discussing the program in Oregon, this essay examines how the Project fared as white collar work, and raises questions concerning the program's usefulness as an effective justification for government subsidy of the arts. This present study can also serve to test various observations made by both the admirers and detractors of the Writers' Project. 
FOOTNOTES

1. Saul Bellow, "Skepticism and the Depth of Life," in James E. Miller Jr. (ed.), The Arts and the Public (Chicago, 1976), p. 13.

2. The name was changed to WPA Writers' Project in 1939.

3. The name was changed to Works Project Administration in 1939.

4. Samuel I. Rosenman (ed.), The Public Papers and Addresses of Franklin D. Roosevelt, IV (New York, 1950), p. 96.

5. Records of the Works Project Administration related to the Oregon Federal Writers Project, Oregon State Archives (Salem, Oregon). U. S. National Archives and Records Service, Records Relating to the WPA Writers' Project in Oregon, 1935-1942. Record Group 69: central correspondence file of the Works Project Administration--state series (Washington, D. C.; General Services Administration, 1968), (Microfilmed). i.e., Workers of the Writers' Project of the Works Project Administration in the State of Oregon, Mount Hood: A Guide (New York), 1940); Workers of the Writers' Project of the Works Project Administration in the State of Oregon, Oregon: The End of the Trail (Portland, 1940). Howard Mckinley Corning, former writer for the Oregon Writers' Project, interviewed by Thomas Ptacek, Portland, Oregon, April 6, 1973.

6. Ray Allen Billington, "Government and the Arts: The WPA Experience," American Quarterly, XIII (Winter, 1961), pp. 466-469.

7. Jerre Mangione, The Dream and the Deal: The Federal Writers' Project, 1935-1943 (Boston, 1972), pp. 365-371.

8. Ronald Taber, "The Federal Writers' Project in the Pacific Northwest: A Case Study" (Ph.D. dissertation, Washington State University, 1969), p. 1. This work is an unpublished Ph.D. dissertation done by Taber at Washington State University. It is available from University Microfilm, Ann Arbor, Michigan.

9. "WPAccounting," Time, XXXXI (Feb. 15, 1943), p. 96.

10. Taber, p. 1 .

11. Billington, pp. 476-486. 
12. Harry Hopkins was chief administrator of the WPA from 1935 to 1939.

13. Mangione, pp. 373-374.

14. Paul K. Conkin, The New Deal (New York, 1967), p. 59. William E. Leuchetenberg, Frankl in D. Rooseve $7 t$ and the New Deal (New York, 1963), p. 127. Alfred Kazin, On Native Grounds: An Interpretation of Modern American Prose Literature (New York, 1942), pp. 501-503.

15. Carl N. Degler, Out of Our Past: The Forces that Shaped Modern America (New York, 1959), p. 390.

16. Mangione, p. 95.

17. Ibid, p. 51 .

18. Mable S. Ulrich, "Salvaging Culture for the WPA," Harper's Magazine, CLXXVIII (May, 1939), p. 653.

19. Billington, pp. 471-475.

20. Taber, pp. VI-VII. This thesis is greatly indebted to the ground work Ronald Taber has laid for it in doing research on the Oregon Federal Writers' Project.

21. Ibid., p. VIII. 


\section{CHAPTER II}

\section{A NATIONAL VIEW}

In the midst of the economic devastation of the Great Depression, Franklin D. Roosevelt, the Democratic nominee for President in 1932, castigated the Hoover administration's deficit budgets as "the most reckless and extravagant past that I have been able to discover in the statistical record of any peacetime Government anywhere, any time." Roosevelt suggested that if he were elected President, he would maintain a balanced budget and at the same time resolve the fiscal woes of the nation. ${ }^{1}$ Yet for all of this rhetorical praise of balanced budgets, Roosevelt, once elected President, could not ignore the suffering that the depression had brought to the American people. It was estimated that at the height of the depression in 1931 and 1932, over thirteen million people, or one-quarter of all the wage earners and their families, were destitute. Only twenty-five percent of the destitute were receiving any kind of public assistance. ${ }^{2}$ Roosevelt and his advisors, conditioned by their Progressive backgrounds, could not ignore this mass of hungry, unemployed people. The New Dealers were basically "conservative men who unquestionably believed in the American free enterprise system" but "part of their Progressive legacy was also a humanitarian belief in social justice." This humanitarian impulse was shared with Roosevelt by Herbert Hoover, but Roosevelt, unlike Hoover, was more willing to experiment with programs to aid the unemployed. While Hoover 
was reluctant to spend money on direct and work relief programs, Frankl in Roosevelt increasingly found it desirable to do so for both humanitarian reasons and political expediency. ${ }^{3}$

The new President's major aim was to preserve the American system, including the corporation-dominated economic structure, and his New Deal programs reflected that intent. Judged realistically, Roosevelt was neither a saviour of the suffering masses, nor an evil puppet of the corporate elite, but merely a product of early twentieth-century progressivism whose world was confined to the goals and aspirations of this philosophy. With his background, it was understandable that his purpose would be one of restoring corporate capitalism to economic security, a purpose that included helping the consumer to increase his earning and buying power. By using "the federal government to stabilize the economy and advance the interests of the [business] groups, Frankl in D. Roosevelt directed the campaign to save large-scale corporate capitalism." Roosevelt managed to do this by recognizing new political interests and extending benefits to them. The inclusion of these people into the established order muted their opposition to big business and the organization of the economy. Roosevelt also wisely provided extensive assistance to the needy which placated their criticism of the government.

- Sensitive to public opinion and fearful of radicalism, Roosevelt acted from a mixture of motives that rendered his liberalism cautious and limited, his experimentalism narrow. Despite the flurry of activity, his government was more vigorous and flexible about means than goals, and the goals were more conservative than historians usually acknowledge. 
Roosevelt was unwilling to adopt any central, economic planning or public management of the business system. Instead, he attempted to stimulate private business with massive amounts of money with the hope of creating new jobs through the National Industrial Recovery Act (NIRA). This program initiated the Public Works Administration (PWA), which spent millions in public funds on work projects for the unemployed. 5 Soon after, the Federal Emergency Relief Administration (FERA) became the third relief program with $\$ 500,000,000$ in funds for grants to nearbankrupt state and city relief agencies. ${ }^{6}$ In the Fall of 1933, with unemployment still high, the Roosevelt administration created another program, the Civil Works Administration (CWA) as a temporary federally supported work-relief program? These programs (PWA, FERA, and CWA) established some of the early guides to all work-relief programs of the New Deal. The rules specified that the relief program must be useful; people on work-relief must not displace regular public employees from their positions; and projects were required to be on public, and not private property. ${ }^{8}$ The major aim of these programs was the substitution of work relief for direct relief, and with the creation of FERA, another goal became, for the first time, the diversification of work relief programs, and the improvement of their standards, so that jobs could be provided in accordance with the skills of the unemployed. 9 By 1934, the Administration began to realize that existing relief. policies were still not adequate to handle the unemployment problem. The PWA, under the direction of Harold Ickes, had an allocation of over three billion dollars but moved too slowly to have any quick effect on the economy. The Federal Emergency Relief Administration lacked the 
strong, central control needed to change the situation. The CWA, while reaching a peak employment of over four million in January of 1934, was designed to be only temporary. Because of the failure of these programs, Roosevelt and his advisors decided that it was necessary to commit the New Deal to an even larger work-relief program. ${ }^{10}$ The President gave the first indication of this new program in his message to Congress on January 3, 1935:

Work must be found for able-bodied but destitute workers. The Federal Government must and shall quit this business of relief. I am not willing that the vitality of our people be further sapped by the giving of cash, of market baskets, a few hours weekly of work cutting grass, raking leaves, or picking up papers in the public parks. We must preserve not only the bodies of the unemployed from destitution, but also their self-respect, their self-reliance, and courage and determination.

The Emergency Relief Act to establish such a work-relief program was passed by Congress on April 8, 1935. With this authorization, Roosevelt issued Executive Order No. 7034 creating the Works Progress Administration (WPA) on May $6,1935 .^{12}$ This program became the New Deal's most ambitious plan for relief and represented the continuing evolution of the concept of work-relief during Roosevelt's administration. In 1935, the appropriation of $\$ 4,880,000,000$ represented half of the total federal budget, and became the largest single appropriation in American history to date. 13

To head the WPA Roosevelt selected Harold Hopkins, the director of the defunct FERA project. Hopkins, a graduate of Grinnell College, had spent his entire career, before joining the New Deal, as a social worker in New York. Soon after accepting the position as director, Hopkins announced that the main role of the WPA was to put over three million unemployed people back to work as quickly as possible. ${ }^{14}$ 
Hopkins believed in what one person described as a "soft work program." That is, he emphasized programs where numerous projects were undertaken, and most of the funds appropriated were to be spent on labor rather than materials. This position was directly contrary to that of Harold Ickes, Secretary of the Interior and director of the PWA, who felt that work relief programs should use large amounts of material, and employ business standards in hiring. Such an approach, Ickes argued, was more consistent with popular relief ideology, because the burden of employing people was left to the business community. ${ }^{15}$ The difference in administrative philosophies between these two men led to a conflict over the set-up of the WPA. Ickes feared that if the WPA followed Hopkin's approach to relief, it would create new opposition to the administration, since it would be a "glorified CWA program." The CWA had been vehemently attacked by many as a wasteful "leaf raking project."16 Therefore, Ickes responded to the WPA program by writing:

I have no confidence myself in Hopkins' program. . . its absurdities, its inefficiencies, its insufficiencies, its bunglings and its graftings will be aired in the press and from the platform and I don't see how we can defend it. The whole program seems to me to be based upon an economic and social fallacy. The more I think of it, the more convinced am I that the only sound procedure is a program of worth-while public works. I happen to believe that secondary employment is more important than employment at the site. . However, no one has been able to mention indirect employment to the President for a long time. . . Hopkins has finally convinced him that the goal ought to be to put men to work, regardless of what they were being put to work at, and if there is no legitimate work, to put them to work notwithstanding. 17

In some ways Ickes' fears were fulfilled. Hopkins had become known by many New Deal enemies as "the give away chief," and though the WPA would prove itself to have tight administrative control of its programs, 
it would never dispel the "leaf-raking" notion. A Gallup poll in 1939 showed the WPA to be the New Deal's best loved, and, at the same time, most disliked program. 18

The choice of Hopkins, as administrator of the WPA, proved to be important in determining the character of the program, particularly for the unemployed, white-collar worker. Hopkin's emphasis on the unemployed worker made him more flexible in the variety and type of programs that the WPA would come to sponsor. Among these programs was Federal Project Number One, of which the Writers' Project was part. The WPA staff had been directed to employ "the maximum number of persons in the shortest time possible." To Hopkins, this meant not only the employment of manual laborers, but also of secretaries, file clerks, administrators, painters, writers, and whoever also could not find employment in their chosen field. ${ }^{19}$

Federal Project Number One had some precedent in other New Deal programs. During the CWA experiment, a Civil Works Service (CWS) was started to employ white collar workers. Certain funds for this project were earmarked for cultural activities. In New York City, for example, money was used to aid musicians in forming orchestras, bands, and chamber ensembles. The CWA, under the sponsorship of the Treasury Department, also initiated the Public Works of Art Project (PWAP), which employed some 3,700 artists at the cost of over a million dollars for art ranging from sculpture and mosaics to Navajo blankets. ${ }^{20}$ With the demise of the CWA program in 1934, FERA experimented in funding cultural projects by subsidizing such activities as the mural-painting projects at the Presidio in San Francisco, free band concerts in Portland, Oregon, 
and the Connecticut Writers' Project, which provided the idea for a national writers' program. In general, however, these early arts programs were sporadic and short-1ived. 21

In 1ate 1934, Edward Bruce, the director of PWAP, discussed the idea of a more ambitious arts project with Jacob Baker, an assistant to Harry Hopkins. Baker subsequently suggested to Hopkins that arts projects "would constitute highly valuable projects," if they could be worked into an enlarged relief program. ${ }^{22}$ Conveniently, the WPA provided just such an enlarged program, and Baker began to formulate plans for an arts project, which led to a meeting in May of 1935 between Harry Hopkins and the proposed directors of the various projects to discuss the possibilities of employing needy artists. Attending this meeting were: Hallie Flanagan, chosen to head the theater project because of her experience in working with experimental theater at Grinnell and Vassar; Nikola Sokol off, conductor and composer, who was asked to direct the Music Project; and artist and museum coordinator, Holger Cahill, selected to lead the project for artists. The meeting was held at the home of Henry G. Alsberg, assistant director of the Division of Reports, Statistics, and Records for FERA. Alsberg, as a writer, had become deeply interested in the Connecticut Writers' Project and their guidebook of the state completed under this program. As proposed director of the Federal Writers' Project, he suggested doing five regional tourist guidebooks of the United States using unemployed writers. ${ }^{23}$ It was not until late July, however, that plans were finalized for the arts program. On August 2, 1935 Jacob Baker officially announced that "it is the intention of the Administration to sponsor nation wide projects 
intending to employ persons now on relief who are qualified in fields of Art, Music, Drama, and Writing." 24

During the period following the official announcement of the programs, the directors of each project spent considerable time forming a workable administrative hierarchy. While these projects were administratively part of the WPA, they were treated much differently. For example, most WPA projects were proposed at the local level, sanctioned by the state WPA, and received final approval in Washington. Funding of projects occurred in the same manner. The local level requested the funds from the state organization, which in turn, requested them from the national office. With Federal Project Number One, the power was not decentralized as in the normal WPA set-up, but was centralized in Washington. Each art project had its own national director, regional supervisors, and state directors. Projects originated on the national level and moved down, instead of up, through the chain of command. Funding for the projects came from the national office to each state in allotments according to population and number of unemployed people, and not on requests from the local level. This was done because the 1935 WPA appropriations had set aside twenty-seven million dollars specifically for the use of Federal Project Number One, meaning that the projects could divide the money into lump sums.

Even though each art project had its national and state director, they originally operated administratively through the state WPA offices. In the case of the Writers' Project, many state directors soon found themselves dependent upon the state WPA for everything from hiring policies to office space and equipment. In order to avoid such direct 
dependence upon the state WPA, the Writers' Project was separated administratively from the WPA machinery in January of $1936,{ }^{25}$ and placed under the supervision of Ellen S. Woodward, administrator in charge of Women's and Professional Projects. In some ways, this change only added to the administrative maze. The WPA still provided the financial and manpower needs for the local Writers' Project, while the Division of Women's and Professional Projects served to distribute and enforce administrative functions between the local writers' and the national writers' office, and between the writers' office and the WPA. The confusing possibilities of coordination among these different groups can best be seen by following the road that administrative directives had to follow. While matters concerning editing of the guide could move directly from the national Writers' Project office to the State writers' office, administrative communications had to travel through a lengthly chain of command. Items went from the national administrator of Women's and Professional Projects, to the national director of the Federal Writers' Project. From there they were sent to the regional supervisor of Women's and Professional Projects and then to the state WPA administrator. He, in turn, sent the communication to the state director of Women's and Professional Projects where finally it was sent to the state Federal Writers' Project director. ${ }^{26}$ The administrative bureaucracy often served to hinder the Project because of personality conflicts, political interferences, and inefficiency.

Henry G. Alsberg was charged with organizing a program for the writers. Alsberg had experienced a long and varied career that proved useful as both "head writer" and chief administrator of the program. 
He had been educated as a lawyer but quickly abandoned that profession to become an editorial writer for various national and foreign newspapers. As a journalist, he traveled extensively and covered events such as the German uprisings in 1920 and Russia after the revolution. In the 1920's Alsberg served as director of the Provincetown Theater, where he adapted the Yiddish play Dybbuk for the American stage and watched it become one of the most successful plays of the twenties. With the depression and the election of Roosevelt, Alsberg moved to Washington, D.C., working under Jacob Baker in FERA. His interests in FERA's experiment with a writers' project in Connecticut made him a convenient selection to head the Writers' Project. 27

Alsberg's choice for his assistant was George Cronyn. Cronyn, like his chief, was a writer who also had a diverse career. After receiving his education at the University of Montana and Columbia University, Cronyn ranched in the Southwest, taught college, worked as an apple grower and cowhand in the Northwest, and even tried plumbing for a while. ${ }^{28}$ His main duty was to supervise the editing work done by the headquarters staff. Cronyn did this with what seemed to many, a vengeance. For example, he informed the director of the New York City Project that his publication, Your New York, "was afflicted with the cheapest sort of ballyhoo," and was a hindrance to the "quality of the Federal Writers' output." 29 As editor, Cronyn showed particular interest in the materials written in the Pacific Northwest, since he had spent much time living in four western states, including Oregon, and regarded it as his sacred obligation to preserve "every bit of quality and flavor peculiar to the west." 30 
The first major duty of Alsberg and his national staff was to choose state directors for each of the state writers' projects and to see that all states developed competent staffs. In choosing state directors, Alsberg sought men who were not only skilled writers and editors but were also good administrators, capable of working with the administrative heirarchy. ${ }^{31}$ Besides selecting people with high qualifications, Alsberg also wanted those who could help keep the program free from political interference. This was often next to impossible. In Missouri, for example, the Pendergast political machine forced Alsberg to choose Geraldine Page as state director. Page soon proved to be completely incompetent, angering her staff to such a degree that they went on strike. Alsberg convinced Page to resign and replaced her with Esther Marshall Greer, who was equally unqualified. Alsberg, in frustration, closed the project for a few months until he could find a capable director. 32 Perhaps just as disturbing were the problems encountered in Washington state, where Alsberg, while finding a competent director in Anne Windhausen, was eventually forced to close the project because Windhausen was attacked for maintaining communists on the payroll. The entire program became a political hot potato between two factions of the Democratic party. State Senator Mary Farquhauson, using accusations by a dismissed employee of the Writers' Project, attacked Windhausen and the Project on totally unfounded charges of leftist leanings. Local newspapers were quick to pick up on the charges and Alsberg was forced to close down the program in August of 1939. It reopened for a short period a few months later, but was closed again for good in March of 
1939, without a single publication to its credit. It was left to the Oregon Writers' Project to edit and complete the Washington State Guide. 33

That Alsberg was able to find qualified directors at all is surprising. The high standards innate to the position meant that many people Aisberg wanted for the job were already employed elsewhere, since they generally possessed professional qualities which could garner them a position even in the midst of a depression. The low pay also insured that few of those qualified for the job would consider leaving their secure positions for the rigors of a state directorship. In late 1936 the annual salary for a state director ranged from $\$ 1,800$ to $\$ 3,600.34$ This led some to scoff at the national writers' office. The Pennsylvania State director of the WPA was shocked when he found that the pay for the state writers' director was $\$ 2,900$. The WPA director informed Cronyn that at that price he would be lucky to find a dishwasher, and insisted that the pay be raised to $\$ 4,000$, which Cronyn reluctantly did. 35 To limit salary costs, Alsberg often found it convenient to hire parttime state directors. But part-time directors raised problems, as in Oregon, because such directors could not often provide adequate supervision to the Project. 36

. Included in the first group of state directors selected by Alsberg were sixteen newspaper people, seven novelists, nine college professors and instructors, three historians, a poet, a bookseller, and a dramatist. The national office continued to find it necessary, however, to replace state directors. Only a quarter of the original state directors lasted long enough to see a book published by their state. 37 
The high turnover rate in state directors often led to confusion in the state programs. New York City, which for the sake of convenience had its own project separate from the state project, was particulariy susceptible to the revolving director game. The New York City Project went through at least six directors, none of whom were able to handle the unruly program which suffered frequent staff strikes. ${ }^{38}$ Wisconsin also had severe difficulty maintaining directors. Dr. Charles Brown, curator of the Historical Museum at the University of Wisconsin, became the first Wisconsin state director, but gave only part of his attention to the Project. Because of this some of the directing was done by a young woman expert in folklore. Soon the curator resigned from the FWP, the folklorist retired, and they were married. A new director came in and changed the Brown policies. But he stayed only a short while, and John J. Lyon became the third director. Lyon brought still different policies and procedures. 39

State directors had similar problems securing a competent staff and controlling them. Directors of state programs were under orders to hire writers who had been certified "as in need" by a local or state relief agency. Nationally, relief rolls indicated there were two thousand such people in the fall of 1935, however, the national office soon discovered, much to its dismay, that a "writer," according to the United States Civil Service Commission standards whose guidelines relief agencies used in classifying people, was anyone who had ever had his words in print. A majority of so-called "writers" were "hacks" incapable of writing any prose whatsoever. Because of this, the state directors were soon begging permission from the national office to hire highly qualified writers who, 
while possibly destitute, were not certified as such. Many qualified writers were not certified because they were either too proud to seek relief status or they found enough piecemeal work to disqualify them from relief rolls. WPA rules, however, specified that ninety percent of all employees had to be on the relief rolls and only ten percent could be non-certified, that is, not on relief. ${ }^{40}$ This rule was to be the curse of many state projects and led Mable Ulrich, state director of the Minnesota Writers' Project, who felt she could not find enough competent writers, to remark that she "did not dream how large a portion of our [state] guide it was to be my destiny to write. ${ }^{41}$ In the case of Idaho, the director, Vardis Fisher, claimed he was unable to find competent writers. He used his staff for clerical and stenographic work, and wrote the entire Idaho State Guide himself. ${ }^{42}$ Eventually some states were allowed to hire as many as twenty-five percent non-relief writers, but the problem of getting writers was never solved. Not only were there not enough of them on the relief rolls, but few talented writers stayed very long on any project. Generally, better writers soon left the Project for higher paying jobs. Most of the remaining project writers either were too young or too old for any other job, or were marginal writers. While employment of writers in the private sector was the stated goal of the project, job mobility generally made it difficult to carry out the writing goals of the project on a consistent basis. ${ }^{43}$ Alsberg surveyed his state directors in 1938 to find out what kind of people the Project had employed, and how they were employed. He received a response from thirty-five state directors employing a total of 2,316 persons. This survey showed that about three-fourths 
of the employees were assigned to do editorial, literary, research or reportorial work. This group of 1,722 was broken down

into 83 nationally known writers, 107 who have held important editorial posts, 105 who have more than statewide reputations as scholars, educators, or research workers, 393 who have sold to magazines and newspapers but who are not nationally known, 159 'beginning writers with promise,' 158 who have done a little newspaper work for which they have received only local or state recognition, and 213 unclassified workers.

The remainder of the employees were stenographers and secretarial staff.

At its height in March, 1936, the Project employed more than 7,500 people, but a more realistic average for the program during the first three years of its existence was between four and five thousand. 45 These workers were provided with what the Project described as "an automat and hall bedroom existence." 46 About ninety-five percent of the Project workers received security wages which guaranteed a survival (or security) income according to the living standard of each geographic region in the nation. For example, security wages in New York City during 1938 were $\$ 93.50$ a month, while they were only $\$ 50$ a month in the south. Oregon was on par with and often above the national average, particularly Portland, where the prevalent security wage approached $\$ 90.47$ Administrators and non-relief writers were paid above security wage, depending upon how much the state project could afford.

Once Alsberg finished organizing his own staff and seeing to it that each state had a functioning program, he was able to set his writers to work. He had unpretentious goals for the Project in mind. Alsberg did not necessarily view the Writers' Project as a patron of 
the arts that would spark a new age in American literature. Instead he concerned himself with writing programs that would employ as many people as possible. Alsberg was realistic about his goals. He recognized that many of the Project employees were not polished writers, but white collar workers who saw themselves as writers of sorts. Consequently, Alsberg proposed that his writers produce guidebooks of the United States.

A number of considerations led the Project leader to believe that a series of guides of the United States would be the best project for the writers to undertake. For one thing the national director noted the success of the Connecticut Guide sponsored by FERA's Connecticut Emergency Relief Administration in 1934. This project had used a few skilled writers who had compiled the contributions of thousands of volunteers, researchers, and writers into a comprehensive guidebook. Since there were over 2,400,000 unemployed professional and service workers in the country and only 2,000 of these were writers, Alsberg reasoned that a guide on the order of Connecticut's would be able to use not only writers but researchers and clerical workers, thus employing as many people as the Project could afford to carry. A guide, Alsberg argued, would be more realistic than individualistic works such as novels and plays, since a larger number of people could be employed. even though literary quality might be sacrificed. ${ }^{48}$

Connecticut's guide, Alsberg believed, also indicated the need for a guide to the United States. Baedekers, first issued in 1893 and revised in 1909 was the last comprehensive guide to this country. By the 1930's this guide was admittedly dated. With observations 
"that travel on this side of the Atlantic was as safe as in the most civilized parts of Europe," and suggestions that the tourist need not carry a gun but should bring his own matches, buttons, and dress gloves, Baedekers presented a provincial picture of the United States. ${ }^{49}$

A new guide, the national writers' office propagandized to the business community and the press, could be beneficial culturally and economically, if it were pleasingly written and accurate. To garner support for the guide concept, Alsberg played upon the economic interest of the tourist industry and local boosters. He repeatedly insisted that the guide would aid business by stimulating interest in many sections of the nation still unappreciated. George Cronyn, echoing his chief in defense of the proposed guide project to the editor of the New York Times, touched upon the idea that the guides would pay "perpetual dividends--through the sale of guides, stimulation of travel, and investments." 50

Another important consideration in the selection of a project guide was the understanding that the guide permitted governmentsubsidized writing which would not reflect the political, social or economic beliefs of the authors. This was very important in the 1930's when so many writers seemed given to writing "proletariat" literature. Alsberg shrewdly realized that he would have enough problems with the critics of the Project, without adding the charge of leftist sympathies to the list of accusations. He expressed his views on the problem in a letter to the editor of the Saturday Review. 
The problem of dealing with writers was a more difficult one than that of dealing with any other class of the unemployed. The administration had to avoid instituting any projects which would make the government responsible for the opinions and convictions of writers from all classses of society and of varied political and economic beliefs.

The national director soon discovered, however, that no matter how innocuous his guides might be, they would still be attacked as tools for leftist propaganda.

Once the guide series had been selected, the national office found it necessary to establish regulations and guidelines for researchers, writers, and editors. Washington, in numerous and constantly revised manuals, directed every move the state projects made. For the most part, all regulations governing the writing and editing of the guides across the country were standardized. As the manuscripts following these guidelines began to flow into Washington, the national office soon realized that the proposed five-volume guide to America was too confining for the volume of received material and decided to allow each state to prepare its own individual guide. 52

These manuscripts were written according to directions compiled by Cronyn in the American Guide instruction manual. The manual asked for essays on various aspects of the state and tours of the larger cities and highways that might interest a tourist visiting the state. The guide was to begin with an introductory essay on relevant information to the visitor, such as accommodations, transportation, climate, recreational areas, and state laws. The first section of the guide followed the introduction with essays on history, government, racial and foreign elements, educational facilities, folkways and folklore, 
industry and commerce, sports and recreation, flora and fauna, natural resources, and the contemporary scene and culture. Next was a section with the descriptions of important cities, towns, and villages; followed by a third section with "points of interest;" and concluding with a fourth section on highway tours and tours to the points of interest. 53

The state Writers' Projects busied themselves with compiling material suited for the guides. Upon completion of an essay or highway tour, it was forwarded to Washington for editing. First, experts in various fields were asked to look at the submitted material and offer suggestions, but the bulk of the editing was done by the full-time editorial staff in the national office under the direction of George Cronyn. Controversy soon raged over the competence of Cronyn and his editorial staff. Many of the editors were ignorant of the states they were dealing with and found it necessary to rely upon inaccurate and outdated secondary sources to check the accuracy of each manuscript. Added to this problem of checking material was the constantly changing and often confusing instruction manual. This meant that many manuscripts submitted by a state to the editors were out-dated because the instructions on content or writing style had changed. Editors repeatedly sent back material to state directors, telling them to start over with the newly issued instruction manual. At one point, when relations between some of the state Writers' Projects and the editorial staff had become overly strained, Cronyn found it necessary to give his staff a stern lecture on unduly antagonizing the state projects. Cronyn should have followed his own advice. He seemed convinced that he was an expert 
on every state, a position which infuriated more than one state director. 54

Cronyn's editorial power was considerable. Not only did he edit style, but since each essay or tour was written on a word-allotment system, Cronyn had the power to decide how many words each essay and tour could have. Cronyn decided both the content and coverage of every item in the state guides. Of course it would have been physically impossible for him to cover every page of manuscript that flowed into his office when he was editor of the project. To ensure proper editing he issued strict guidelines to his staff to watch for balance and proportion in the guides. Cronyn advised the editors that the importance of each attribute must be measured in the number of words devoted to $i t$, and warned them that just because an essay was well written or interesting "is not a reason for allowing it disproportionate space." He noted that many states devoted too much space to the trivial and to self aggrandizements. For example, he noted that some states with poor educational systems spent too many words praising their educational systems, or states with little culture often made themselves appear to be the cultural center of the United States. To avoid this and various other excess verbiage, Cronyn specified that guidebooks were to use only one-quarter of their total page allotment for essays, with the rest going to town descriptions and highway tours. City essays were allotted wordage by population size and highway tours by the relative interest of the area being described. 55

The battle with national editors over manuscripts proved to be one of the major frustrations for many state directors of the Writers' 
Project. The director of the Minnesota Project, Mable S. Ulrich, complained that "of the federal editorial staff some had taught English, a few had worked for newspapers, others had written an occasional novel or short story. But very few had ever before been editors." According to UTrich, the editors seemed to make up in vengeful enthusiasm for what they lacked in experience. U1rich protested against excessive editing, particularly differences of opinion over factual material, and argued that her staff had firsthand knowledge of the subject. The federal editors told her that the state writers were too close to their subjects "to get a perspective." Once, in exasperation over such a confrontation with an editor, Ulrich asked the national editor if she had ever been to Minnesota. The woman replied that she had not but that she had been to Maine.

This type of dispute led to one of the most amusing and absurd stories of the entire Writers' Project. When the Minnesota Project submitted the cover design for their guide to the national office with "tiny gophers," the state animal, on each lower corner, they were informed that the gophers' tails were too long. Ulrich responded to this charge by providing a description of the state animal from the gopher case in Minnesota's Natural History Museum. The national office preferred to stand by their shorter tailed gopher much to the chargin of the Minnesotans. Ulrich gave up in utter disbelief. 56 Disagreeing with the critics of the national editorial staff, Bernard DeVoto, former editor of the Saturday Review, insisted that one of the reasons for the generally high quality of the completed state guides was the editing they received by the Washington office. ${ }^{57}$ 
The national editors did counter the wordiness and "local boosterism" of state projects. But problems such as imprecise and ever-changing instructions, and frequently rude and pretentious editorial criticism hampered the working relationships between the national office and the state projects.

Once the guide had successfully made it through the watchful editors, it was ready for publication. Initially, the national office hoped to have the federal government print the guides. After the Government Printing Office released the guide for Washington, D.C., Alsberg decided that considerations of quality, design, efficiency, publicity, and distribution required private printing. ${ }^{58}$ Most publishers were quite receptive to the idea, particularly to publishing guides to the more populous states. In order to encourage publishers to consider doing guides to smaller and less attractive markets, Alsberg let publishing contracts to the guides in sets of three. This, for example, meant that if a publisher wanted the rights to print the Florida guide, he would also have to agree to print and market the guides to South Carolina and Maryland. 59

Since the government could not copyright the guides, each book had to be sponsored by a state or public agency such as a public. library, historical society, or secretary of state's office. The sponsor not only copyrighted the guide, but, theoretically, assumed full obligations for the costs of the publication. For this consideration the sponsor was allowed to set a price for the guide, generally ranging from $\$ 1.50$ to $\$ 2.50$, which allowed them to get their investment back. Any money made above the original investment was used for 
future printings, for non-labor costs of the project, donated for installation of historical markers in areas mentioned in the guide, or returned to the federal government. ${ }^{60}$ All of this was theoretical, however, because only two states, Wisconsin and Oregon, actually committed money to the publishing of the guides. In most other cases the publishing firms undertook the cost of publishing with a guarantee by the sponsor to purchase part of the first printing. 61

With the multitude of administrative, staff, and writing problems, it is hard to believe that the Federal Writers' Project eventually finished its goal of guidebooks to all of the states. Although the Writers' Project was begun in the fall of 1935, it was not until 1937 that the first guides, for Idaho, Washington, D.C., Massachusetts, and Vermont were published. ${ }^{62}$ But not only did the Project manage to complete guides to each state, it also produced numerous books, articles, magazines, pamphlets, and other ephemera.

Much to the consternation of Alsberg, who had hoped to see Washington: City and Capital achieve the honor, Idaho: A Guide in Word and Picture was the first guide to come off the press. ${ }^{63}$ Perhaps it was fortunate for the Writers' Project that it did, for the high quality of the Idaho Guide made many of those who had critized the program reassess its value and potential. After reading the guide to Idaho, Bernard DeVoto editorialized in the Saturday Review that fifty-odd volumes of the national guide, if they are up to this standard will not only vindicate the Writers' Project but will heighten our national self-consciousness, preserve invaluable antiquarian material that might have perished, and facilitate our knowledge of ourselves. 
While the Idaho Guide was busy proving the possibilities of the program as a literary movement, Massachusetts: A Guide to its Places and People, engendered a political controversy that raised the question of censorship, and provided the first major skirmish between the supporters of the Project and those who would destroy it. When the Massachusetts guide was published, an enterprising reporter for the Boston Traveler discovered that the guide allotted more space to the controversial Sacco-Vanzetti case than to either the Boston Tea Party or the Boston Massacre. The Traveler headlined their paper with "SaccoVanzetti Permeate New WPA Guide." Governor Charles F. Hurley of Massachusetts attacked the "communist" control of the Writers' Project in Massachusetts, and Senators Joseph Walsh and Henry Cabot Lodge, Jr. demanded that Harry Hopkins launch an investigation. The White House ignored the uproar but did appoint Louise Lazell to censor all future manuscripts for what could be controversial material. 65

With the controversy over the Massachusetts Guide and sensational news headlines over the strike-ridden New York City Project, which had become a battlefield between Stalinists and Troskyites, ${ }^{66}$ Martin Dies, chairperson of the House Committee on Un-American Activities, decided to conduct investigations of the Writers' Project during the summer of 1938. Ignoring both the accomplishments of the Project and Alsberg's defense of the program, Dies played up the testimony of disgruntled ex-employees. Alsberg's censor Louise Lazell also offered the committee the kind of information it wanted to hear. Lazell asserted that Alsberg was personally responsible for the insertion of "communist teachings or phraseology" into the state guides, and that he was 
conducting the entire Project to the detriment of the American business community and the government. 67

The House Appropriations Committee, out to cut WPA funds, seized on the Dies Committee attack in 1934, and accused Alsberg's project of pro-communist sympathies, boondoggling, and sub-literary production. In the end, the Writers' Project fared much better than the Theater Project, which was killed by the committee. But section twenty-five of the 1939 WPA appropriations did stipulate that the Writers' Project could no longer receive its sole financial support from the WPA. Instead, the program would have to receive at least twenty-five percent of its funds from local sponsors. The same section also specified that no employee could remain on the project for more than eighteen consecutive months without having his or her status reviewed. This meant that in many states the Writers' Projects had to close down not only until they found a willing sponsor, but until their employees had their relief certification renewed. Despite the controversy over the Project, however, all the states soon had sponsors and were once again functioning under the new name, WPA Writers' Project. 68

Henry Alsberg, the originator and designer of the Federal Writers' Project, could not withstand all the controversy that the program was generating. Colonel F. C. Harrington, the new WPA administrator, discharged Alsberg on August 9, 1939, for reasons of "bad administration."69 Harrington replaced Alsberg with John Newsom, an ex-army. officer, writer, and one-time director of the Michigan Writers' Project. Newsom was very unlike Alsberg, being less a creative editor and more 
of an administrator. His goal was to finish the thirty-one guides that Alsberg failed to complete. This he did remarkably well, completing twenty-eight during the first year as administrator. Time quoted the terse philosophy of the new director who told the magazine that "the [the Writers' Project] is a production unit, and it is work that counts. I've never been for art for art's sake alone." 70

While Newsom proved to be an efficient administrator, the changes in the Project and severe budget cuts began to hurt it badly. The national office, suffering from staff cuts, could no longer supervise and edit materials properiy. The new rule requiring financing by sponsors left many Projects at the mercy of their sponsor, who in some cases used the Writers' Project to turn out local propaganda on the virtues of the area. The need for continued sponsors' support and a fear of provoking the Dies Committee once again helped to weaken the program even more by forcing the Project to give up social-ethnic studies and collections of "living lore" for less controversial projects as state "Factbooks" and recreation guides. A program never having great literary pretensions now moved even further away from creative writing programs towards more functional tasks. ${ }^{71}$

The Project lasted on the national level until 1943. Most state projects closed between 1940 and mid 1942, many having published only their state guides and a few pamphlets. Those projects still existing in 1941 soon found themselves writing propaganda for the war effort. In 1942 the Project reported to Congress, 
The Writers' Projects do not attempt to create literature nor to develop talent. They employ and train needy people who are not absorbed by the nation's armed or industrial forces on tasks officially requested by local unjts of the army, navy, or civilian-defense organizations.

As with many other New Deal programs, World War II brought an end to the Writer Project. By the time the national office closed in February, 1943, the Project had produced 48 state guides, 30 city guides, 20 regional guides, and thousands of other pieces of ephemera, much of which has never been cataloged. The cost per publication could be considered high. The project spent over $\$ 27$ million with one thousand cataloged publications to its credit. Consequently, each publication cost $\$ 27,000$, an extremely high price to pay for some items only a few pages long. ${ }^{73}$ Yet the Writers' Project had not promised to be inexpensive, nor had it promised great 1 iterary works. It had promised to take people off relief rolls, and did accomplish that task. The Project helped not only unemployed writers but thousands of others who were employed to do research and type manuscripts. Most of those who worked for the Project could not be considered writers in even the humblest sense of the term, but some, such as Conrad Aiken, Saul Bellow, and Richard Wright, were given a chance, and preserved their writing talents for future generations. ${ }^{74}$ For these assets, no price can be assessed.

To judge the accomplishment and failures of the total Project, it will be useful to see how the Writers' Project fared in one state. By examining the Project in Oregon, one will be able to see how the program functioned as a tool for employing white collar workers in their chosen field, as a governmental project with an administrative 
hierarchy and all the problems inherent in such a bureauracy, and whether or not the Project can be used as an effective judge of government sponsorship of the arts. 


\section{FOOTNOTES}

1. Frank Friedel, "The New Deal in Historical Perspectives," in

Twentieth Century America: Recent Interpretations, ed. by Barton J. Bernstein and Allen J. Matusow, (New York, 1969), p. 249.

2. Ibid., pp. 247-48.

3. Ibid., pp. 249-250.

4. Barton J. Bernstein, "The New Deal: The Conservative Achievements of Liberal Reform," in Towards a New Past: Dissenting Essays in American History, ed. by Barton J. Bernstein, (New York, 1969), p. 267.

5. Ronald Taber, "The Federal Writers' Project in the Pacific Northwest: A Case Study" (Ph.D. dissertation, Washington State University, 1969), p. 8.

6. William F. McDonald, Federal Relief Administration and the Arts (Columbus, Ohio, 1969), p. 25 .

7. Ibid., pp. 52-54.

8. Ibid., p. 16 .

9. Ibid., pp. 35-37.

10. Taber, p. 10. McDonald, pp. 53-54.

11. McDonald, p. 103.

12. Ibid., p. 104 .

13. Taber, p. 11 .

14. McDonald, pp. 27-31.

15. Taber, pp. 11-12.

16. Ibid., p. 9.

17. Searle F. Charles, Minister of Relief: Harry Hopkins and the Depression (Syracuse, New York, 1963), pp. 124-125. 
18. Taber, pp. 13 .

19. Ibid., pp. 13-14.

20. McDonald, pp. 59-63.

21. Ibid., pp. 71-80.

22. Ibid., p. 116 .

23. Taber, pp. 16-17. McDonald, p. 129. In 1936 a Historical Records Survey (H.R.S.) under the direction of Dr. Luther Evans was added to Federal Project Number One. This project gathered, sorted and classified historical records for archives, libraries, and other public organizations. In many states the HRS was directly associated with the Writers' Project. In Oregon, for example, many members of both programs were used interchangeably. Much material gathered for the guide done on Oregon was collected for the Writers' Project by the Historical

Records Survey.

24. McDonald, p. 131 .

25. Taber, pp. 16-17.

26. Ibid., pp. 37-39.

27. Jerre Mangione, The Dream and the Deal: The Federal Writers' Project, 1935-1943 (Boston, 1972), pp. 365-371. McDonald, pp. 663-665. Taber, p. 18.

28. "Jack of all Trades: But George Cronyn Adds Arts to Mastered Crafts," The Evening Star (Washington, D. C.), Nov. 5, 1935. This article was deposited in the Records of the Works Project Administration Related to the Oregon Federal Writers Project, Oregon State Archives (Salem, Oregon). Mangione, p. 59.

29. Taber, p. 18.

30. George Cronyn, Associate Director of the Federal Writers' Project, to Reed Harris, an assistant director of the Federal Writers' Project (memo), Jan. 26, 1938. Unless specifically cited otherwise the documents cited herein are held in Record Group 69: central correspondence files of the Works Projects Administration, Records of the Federal Writers Project, Records of the Central Office, National Archives (Washington, D.C.). 
31. McDonald, p. 671 .

32. Mangione, pp. 194-199.

33. For an in depth discussion of the problems of the Washington State Writers' Project see Taber, pp. 66-82.

34. Alsberg, "Writers and the Government: A Letter from the Director of the Federal Writers' Project," Saturday Review of Literature, XIII

(Jan. 4, 1936), p. 23.

35. Typescript of a telephone conversation between George Cronyn and Mr. Jones, WPA administrator for Pennsylvania, Oct. 16, 1935, p. 3.

36. Taber, p. 41 .

37. "Mirror to America," Time, XXX (Jan. 3, 1938), p. 55.

38. For a discussion of the New York City project see Mangione, pp. 155-192.

39. Blair Bolles, "The Federal Writers' Project," Saturday Review of Literature, XVIII (July 9, 1938), p. 3.

40. Taber, pp. 42-44.

41. Mable S. Ulrich, "Salvaging Culture for the WPA," Harper's Magazine, CLXSVIII (May, 1939), p. 656.

42. Mangione, p. 203.

43. Taber, p. 43-44, Bernard DeVoto, "The First WPA Guide," Saturday Review of Literature, XV (Feb. 27, 1937), p. 8.

44. Bolles, p. 4.

45. Taber, p. 20.

46. Bolles, p. 5 .

47. Untitled Manuscript Nov. 7, 1935.

48. Taber, pp. 29-30.

49. Robert Bendiner, "When Culture Came to Main Street," Saturday Review of Literature, (April 1, 1967), p. 20. 
50. Taber. p. 30 .

51. Alsberg, SRL, p. 9 .

52. Mangione, p. 47. Actually Alsberg first mentioned a single guide to the United States, but soon changed to the idea of doing five regional guides, before finaliy deciding to have each state do their own guidebook.

53. "Make-Up of the State Guide Book." No date, pp. 2-6.

54. Taber, pp. 32-34.

55. Cronyn to all Washington, D. C., editors of state manuscripts (memo), Sept. 15, 1935.

56. U1rich, pp. 656-57.

57. Bernard DeVoto, "The Writers' Project," Harper's Magazine, CLXXXIV (Jan., 1942), p. 223. Also see Bendiner, p. 21 .

58. Mangione, pp. 220-21.

59. Ibid., pp. 230-31.

60. "Regulations for Publication of State and Local Guide Material," Oct., 1936.

61. "Completion of the American Guide Series," The Publishers' Weekly, CXXIV (May 3, 1941), p. 1815.

62. Taber, p. 21.

63. Mangione, pp. 201-219.

64. DeVoto, SRL, p. 8.

65. Mangione, pp. 216-220. Taber, p. 22.

66. Mangione, pp. 173-177.

67. Ibid., pp. 301-03.

68. Taber, pp. 24-25.

69. "Alsberg Dismissed as Head of Writers' Project," The Publishers' Week ly CXXXVI (Aug. 19, 1939), p. 513.

70. "WPAchievement," Time, XXXVI (Aug. 12, 1940), p. 64. 
71. Mangione, pp. 344-45.

72. Taber, pp. 25-26.

73. "WPAccounting," Time, XXXXI (Feb. 15, 1943), pp. 96-97. Mangione, p. 352 and pp. 369-376.

74. Bendiner, p. 20. 


\section{A BEGINNING: OREGON 1935-1937}

The Federal Writers' Project began in Oregon, as it did in every other state, with a search for a state director to head the program. Henry Alsberg, the national director of the Federal Writers' Project, sought men with both writing talents and administrative ability. In early October of 1935 George Cronyn, assistant director of the Federal Writers' Project, contacted E. J. Griffith, Works Progress Administration Director for Oregon, ${ }^{1}$ and suggested that $H$. L. Davis might prove to be an effective director of the project, if he had the ability to handle forty-five workers, run six offices around the state, and edit a state guidebook. The suggested yearly salary for this work was $\$ 2,600 .^{2}$ The selection by the national office of $H$. L. Davis indicated a desire to have Oregon's most important and influential writer at the helm of the program. Davis, poet and author from The Dalles, Oregon, had achieved notoriety with the publication of his novel Honey in the Horn in early $1935 .^{3}$

Griffith rejected the suggestion that Davis be selected as director of the Oregon program. The WPA administrator wired Cronyn that "Davis is excellent poet and should therefore be very incompetent executive which his friends confirm." Griffith informed Cronyn that the Oregon WPA office intended to recommend someone else. ${ }^{4}$ There is no further indication that H. L. Davis was approached on the subject. 
Perhaps it was just as well, for a letter by Davis in 1936 to project employee, Howard McKinley Corning, showed an impatience with hiring writers to turn out histories and guides. Davis commented on Corning's assigned task of writing a "History of Education in Portland"

It would be amusing if the thing weren't so obvious to point out that one can think up nothing better to do with a genuine and acknowledged poet than to put him to cobbling up gouty particulars about grade school curriculae in 1850 and how to drive to Nisqually without missing the fish hatchery or the panorama of the prune orchards. It would be precisely as idiotic if the WPA artists were hired for their ability ${ }_{5}$ to paint pictures and then put to work whitewashing chicken houses.

The National Office decided to settle upon Alfred Powers, Dean of the General Extension Division of Education for the University of Oregon, as State Director of the Oregon Writers' Project. ${ }^{6}$ Powers seemed to be a highly qualified choice. He was a local writer, who had a strong knowledge of the Oregon literary scene as demonstrated in his 1935 publication of the History of Oregon Literature. ${ }^{7}$ Powers' $^{\text {role as Dean }}$ of the University of Oregon's Extension Division also, it appeared, would give him the administrative experience that $H$. L. Davis lacked. 8

Powers assumed his role as a part-time director in early october and moved into his quarters in downtown Portland at the Myler Building. Powers agreed to work on the project twelve days a month for $\$ 180$. The remainder of his time was to be spent at his Dean's position at the University of Oregon. ${ }^{9}$

Once settled into his office, Powers wired Alsberg and requested funds to hire a staff. ${ }^{10}$ The national office had originally intended to hire forty-five for the staff in Oregon. Powers, apparently believing that Oregon was blessed with a surplus of unemployed applicants, asked that he be allowed to employ seventy-four people because an initial 
check of the welfare rolls had al ready turned up "forty very promising workers."11 A few days after this request, Powers informed the national office that he was ready to hire twenty people but only thirteen of these were on relief. ${ }^{12}$ Griffith interceded at this point and reminded Powers that he could only employ one non-certified (non-relief) worker to every ten workers. ${ }^{13}$ This meant that Powers would have to forego so many nonrelief writers. He went back out in search of more relief writers to meet his needs. Soon Powers suggested to the national office that he be allowed to establish four districts for Oregon's project. District One which would be Portland and have twenty employees; district two, twenty-five employees; district three, twenty employees; and district four, twelve employees for a total of seventy-seven poeple. While the national office did not disapprove of the concept, they did not feel that so many workers were necessary. ${ }^{14}$ Finally, in November 1935 , Alsberg was informed that fifty-six people had been secured, even though funds had been appropriated for only forty-five, and the monthly budget of $\$ 4,700$ was not enough. According to the Oregon office, this many people were needed to cover Oregon's thirty-six large counties. Alsberg also received notice that one hundred people with an appropriate monthly budget would be needed to carry out the program in oregon. ${ }^{15}$

Henry Alsberg, most likely confused over the apparent inconsistencies in Powers' hiring logic, sent George Cronyn to Portland in midDecember 1935. Powers convinced Cronyn with his "sincerity and enthusiasm." Cronyn's favorable report of this meeting to Alsberg encouraged the national director to grant an increase in the quota of 
workers from forty-five to sixty. ${ }^{16}$ In doing so, Alsberg ignored Powers' difficulties in finding enough competent writers on relief to fill the original quota. Although Powers had been warned about hiring too many non-relief writers, he had no other choice but to use them. Frequently, he hired non-relief writers without permission, even when there were not enough funds to pay them. Cronyn and Alsberg, caught up in the enthusiasm of the Oregon director, allowed the quota to be kept so high that Powers could not meet it without non-relief people. This practice was permitted to continue until June 1937, when the national office finally forced Oregon to conform with the non-relief percentage of one non-relief writer to every ten employees. 17

Perhaps only the unemployed and underemployed welcomed Powers' agitation for a larger quota than was feasible. Throughout Powers' two years reign as head of the Oregon program, he was able to keep thirty to fifty employed in the Writer's Project, even though the total relief population in Oregon warranted fewer workers. Since the program was designed to hire as many unemployed white collar workers as possible, Powers was actually helping Alsberg fulfill his goal. This meant that perhaps as many as fifteen Oregonians were given jobs, when otherwise they might have been unemployed or underemployed. 18

Powers' search for qualified personnel, while at times frustrating, actually provided him with a fairly competent staff. Among those serving in leadership capacity were people who were well-educated and had varied writing experiences. Elizabeth Montgomery was Assistant State Director of the Project. Montgomery had received her Masters degree from Stanford and a Ph.D. from Oregon. She had been a teacher 
at both the high school and college levels. Montgomery was employed on the Project at $\$ 150$ a month. She held this position until October of 1936, when she left to accept a full-time teaching position at the University of Oregon. She was replaced by Dr. Louis Berelson, who also worked for the University of Oregon. 19

Stewart Holbrook was hired to be general editor of the Oregon State Guide at $\$ 103.40$ a month. Before joining the project, he had served as an editor of a lumber newspaper, contributed frequently to national publications, and was a feature writer for the Oregonian. In the summer of 1936, Holbrook left the staff to go to New York where he eventually gained some reputation as a writer. Replacing Holbrook as state editor was Thomas Potwin, a Yale graduate, and a life-long newspaper person who had served as editor of the Aberdeen Daily American in South Dakota between 1906 and 1920 and editor of Oregon's Albany Herald between 1920 and 1934. Potwin had joined the editorial staff of the Oregonian in 1934.

Supervising editor of the Oregon Guide was Ada Hedges, hired at $\$ 94.60$ a month. Hedges' Desert Poems had been published in the early thirties. She had also contributed poetry to London Mercury, the Nation, and the New York Times, and had worked for KOAC Radio in Portland. Under Hedges was Claire Churchill, who served as field supervisor for the Oregon Guide. Churchill was the author of Slave Wives of Nehalem and South of the Sunset. 20

The procedure for becoming a staff member of the Oregon Writers' Project was uncomplicated but frustrating for those not on relief. Interested persons applied at the Project office. If the applicant was 
certified and qualified for the position, there was little problem in hiring. If the applicant was not already certified for relief, he or she had to go to the welfare office to apply for certification. Many of these writers were not fully employed but were able to pick up odd jobs either writing and selling individual articles or working on nonwriting jobs. Such incomes could be enough to preclude them from being considered for relief, even though the argument could be made that they were not gainfully employed in the occupation of writing. From the viewpoint of the relief office, these people were not destitute, but from the viewpoint of the writer, living on piecemeal jobs, and from Powers' viewpoint, the jobs supplied by the Oregon Writers' Project were a salvation. More than one time during Powers' tenure he used his influence to convince a recalcitrant relief agent to certify a writer who was having difficulties meeting certification criteria. ${ }^{21}$

Once certified, employees were sent to Elizabeth Montgomery to be assigned to one of the supervisors to work on the Guide. Powers noted that there were "too many employees" for the guide but fortunately "we were allowed to have them do other things." 22 These other projects included city histories, historical biographies, and news articles, many of which were pushed by local chambers of commerce and other booster groups. This practice led the national office to criticize Oregon on the grounds that such projects interfered with the main goal of researching, writing, and editing the Oregon State Guide, which, as in all states, was the main task of the Writers' Project. ${ }^{23}$

Powers was not neglectful of this task. Besides his top staff of Montgomery, Holbrook, Hedges, and Churchill, he had hired a talented 
staff from around the state to work on the guide. By 1936, the group included Vern Bright, a poet and instructor; Lel and Gilbert, former editor of the Albany Evening Herald, Albany Democrat, and Morning Astorian; Howard Mckinley Corning, author and poet; Rose Liebbrand, a former journalist in China; Joe D. Thomison, journalist; and Leslie Hoskins, author. Some other writers in this initial group included Robert Wilmont, Kevin Fitzgerald, Margaret Clarke, Curtis Merrick, Ruby Lovel and, Charles 01 sen, Don Griesy, Robert Schlick, Ralph Sherriff, Fred Smith and Muriel Thurston. ${ }^{24}$ The average salary for these workers was $\$ 94$ a month. 25

These staff members came to the Oregon Writing Project with years of experienced writing. Perhaps illustrative of their varied careers is the story of project member Rose Leibbrand. In 1917, Leibbrand accepted a job as secretary to a Congressperson in Washington, D.C. Caught up in the war-time activities of the nation's capital, she received an appointment as industrial investigator for the War Labor Board, providing her an opportunity to travel throughout the eastern United States to factories in order to resolve labor unrest.

After the war, Liebbrand left for the Far East. Initially she worked for the Shanghai Times in China before moving to another journalistic position in Peking. In the mid-1920's Leibbrand returned to Oregon, attempted to run a restaurant, and finally settled into a job in a civic public relations organization. She was in Oregon when the depression began. Leibbrand remembered: 
On a gloomy November day of 1931, with a deadline facing me, I was busy pounding out a story, extolling our great outdoors. when I saw my chief writer approaching. Sitting down in the empty chair opposite me, he gave one of his quizzical grins, and for some reason my breath caught suddenly. When he leaned and exclaimed, 'God! I'd rather be shot then tell you this,' I first congealed, froze, as it were, with ${ }_{26}$ smile on my face. It was my first experience in being fired.

With thousands of others, Leibbrand began her hopeless search for a job, first in writing, and, finally, in desperation, in whatever she could get.

Jobs had always presented themselves. Each had been more interesting . . . than the one before. . . I began to circulate. Newspaper offices, advertising agencies, I visited them all. Finally I resorted to letters, 2 sending them here, there and everywhere. Nothing resulted.

Destitute, Leibbrand finally found a job doing federal research and then publicity writing for the Works Progress Administration until she was appointed to the staff of the Oregon Writers' Project. 28

Writers such as Leibbrand led Powers to note that the general caliber of his staff was "damn good."29 In fact, Oregon's project appeared to have been more fortunate than others in attracting competent personne1.

Powers' main concern with his staff was not their writing competence, but the scars the depression had left upon these people. Powers was constantly sensitive to the psychological impact the depression had on his staff. Many of his writers were not only young budding writers but others were seasoned professionals who had seen all job prospects in their chosen field dry up; and with it any choice for a livelihood in an occupation that they had spent so much of their lives. Powers 
recalled that he had numerous instances where he "felt like he was father to seventy children." He had one fellow who had taken to drinking binges. Powers did "a little coaxing" and the man turned in some of the projects' "better writing." Another writer was an unemployed minister from Baker, Oregon. Powers believed that the man was a good writer and wanted to make him supervisor of Eastern Oregon. The minister initially refused the position because he had been out of work for so long that he was convinced he was incompetent. Yet, a third employee played revolving doors with the project. Powers remembered him "as not the best writer around." This employee had been out of work for sometime when he was hired by the Project. After a few months, the writer was given a chance to teach at the University of Portland, but the job did not work out and he was soon again on the streets. Defeated, he gave up looking for a job altogether. Powers then offered him his old job back and soon the man was writing again. 30

With a staff of talented writers, Powers should have been able to complete the Oregon Guide in record time. But Powers split the staff's time, so they could do other writing activities besides the Guide. Furthermore, he soon found that with the conflicting rules, changing guidelines, and highly critical editing from the Washington office, the publication of the Guide was not to be an easy undertaking.

Powers agreed that the selection of guide books for the project was a wise decision. Yet, local works were much easier to complete due to the lack of bureaucratic tinkering with those publications. 31 
One of the first editorial reports on the Guide from Washington was extremely critical of the Oregon manuscript, complaining that the focus needed to be rewritten to conform to the most recent form instructions. 32

Another typical criticism was in regard to the contents of the material. The national guide book tour editor, Katherine Kellock, wrote Henry Alsberg that the Oregon state tours did not begin to cover the state adequately, because "there is hardly an indication that Oregon, outside of the ten towns and cities given separate treatment, is anything but the former home of Indians and scenic wilderness. 33 Powers, somewhat chagrined, responded to such criticism by writing back: "We believe (s)he is wrong in some points, as might be expected, with her so far away from the ground. By and large, however ( $s$ ) he had done a good job of appraising our work." Condescendingly, he added that he was "sure the guide will be better for editorial work" from Washington. 34 Soon Alsberg was returning work to Powers, refusing to read work written before the latest instructions were issued. A week later Washington lashed at Oregon for being tardy in submitting material.

In checking over the production records we find that Oregon is very far behind; we have had no copy from you save one tour since early summer. This is a very serious matter; there should be a steady flow 95 essays, and city and tour descriptions sent into this office.

Cronyn's comments unleashed a flurry of copy to Washington, but the national editors continued to criticize much of the new attempts. Among other improprieties, the "Contemporary Oregon Essay" was chastized for containing the statement that "Oregonians are practically a 
'racially pure American Stock." The national office noted that this was uncalled for and meaningless since there was no such thing as a "pure American stock." 36 This incident perhaps served to indicate that not all the editing done by Washington was pointless or unfair. Powers, while frequently critical of the strong administrative control by Washington, felt that the quality of the guides were good because of the high editing standards set by the national office. ${ }^{37}$

Oregon was soon again in trouble with the editors. In November 1936, Katherine Kellock complained that "the Oregon tours. . are beyond question the worst coming in from any state." She demanded that the staff in Oregon be educated as to the tour form once a competent writing staff were assembled. ${ }^{38}$ At the same time Henry Alsberg also expressed dissatisfaction with the project and requested his national field advisor Bob Wells to "get things going" in Oregon. 39 Upon surveying the situation, Wells reported that the ability of the Oregon staff had been underestimated due to one "unfortunate tour sample sent in response to some urgent request for immediate tour material." 40

Criticism of the Oregon material appeared to subside with the tour and essay revisions which continued throughout 1937. Nevertheless, there still were disputes over editorial criticism such as "Bend article is 246 words over its quota, lacks color, "41 and a rebuke of the essays on contemporary culture for "more than a trace of smugness and complacency."42 In writing about the University of Oregon and Oregon State University, local writers were warned to be sensitive to descriptions of those campuses so as not "to offend graduates who tend to be influential." 43 
The guide also received its share of positive comments during this period of time. Cronyn felt good about the progress made on essays and tours sent into Washington, and told Alsberg that the "Oregon copy is in quite good shape. - quality above average." 44 with this flurry of activity, Powers promised to have the Oregon Guide ready for the printers by February, 1938. 45

Powers was never to complete the Oregon Guide. In late September 1937, Oregon Writers' Project workers affiliated with the American Federation of Government Employees, notified Maurice Howe, regional director of the Federal Writers' Project, of their intentions to strike. Out of the fifty employees of the Writers' Project, forty-six announced their intention to joint the walk-out, which coincided with Franklin D. Roosevelt's arrival in Portland to dedicate Timberline Lodge. The employees enumerated a number of concerns. They were:

1. The release of $\mathrm{Claire}$ Churchill from the Project in an attempt to reduce the number of non-certified employees.

2. The retention of a recentiy hired assistant state director, Louis Berelson over Churchill.

3. The use of Berelson by Powers solely for work at Oregon's University Extension Division rather than on project activities.

4. The objection to rewriting guide essays which al ready had been approved by Washington.

5. The fact that due to insufficient funds, the workers were required to pay for road expenses out of their own pockets.

6. The failure of Powers as State Director due to his numerous outside interests, his inaccessibility, his conflicting orders not in line with Washington, which were conducive to waste and effort, and poor administration. 
Also, while the original grievances did not list it, later another complaint was lodged against Powers' retention of Minnie Lee as Assistant State Supervisor of the Historical Records Survey at $\$ 125$ a month. Lee's writing credentials were called into dispute and a question arose as to her personal relationship with Powers. 47 To remedy these problems the workers demanded Powers resignation. 48

Powers was quick to refute the charges made by the workers. He argued that when he was hired for 12 days a month, he had an understanding with George Cronyn that Elizabeth Montgomery could be used to spell him from his duties as Director of the University of Oregon Extension Division, which she did. Montgomery, however, was visible to the workers since she also devoted time to the project. When she left the project in 1936 and was replaced by Dr. Louis Berelson, who solely devoted his Oregon Writers' Project time to the University of Oregon, the workers, rushed by deadlines and other problems with the project, began to question the legitimate usage of Berelson. Powers further compounded this problem by cutting the popular Claire Churchill rather than Berelson when he was order to reduce non-certified personnel. Powers vehemently insisted that he was within rights to use Montgomery and later Berelson in such a manner. The Washington office never was able to dispute this since they could not remember whether or not they had given Powers such permission. But they did decide that the arrangement was unacceptable to them once the state staff raised the issue. ${ }^{49}$

Powers felt that charges stemming from his inaccessibility, poor administration, confusing orders, and failure to properly reimburse employees was dissatisfaction expressed by a few "rabble-rousers." 
He insisted that the whole incident was caused by a few writers, who, at the time, "were flirting with communism." In fact, he initially refused to meet with the workers as a group over the charges and would only meet with them as individuals because "to recognize their complaints by listening to them, would tend to induce Soviet control." 50

Powers tended to blame Ralph Sherriff and Bob Wilmont as the ring leaders, most likely because as union president and vice-president they were the most visible. Powers referred to these two and five others as the "Communist Seven." He claimed to have been approached by a group of them to help organize a communist union before the dispute occurred. His refusal to participate, Powers believed, led to a falling-out with the group and helped to precipitate the threatened strike. 51

Some of the writers for the Oregon Writers' Project may have flirted with the Communist Party, since it was not uncommon practice for writers to do so prior to 1938. One of the project employees, Howard Mckinley Corning, noted that the Portland Police kept a "Red List." According to Corning,

There were about 56 or thereabouts individuals [on it]. Some eight or ten of these were from the Writers' Project and Historical Records Survey. We know some of them had capabilities and did their job but they were generally in the mood to unionize some form of opposition. There were several little organizations. - the office workers union was one of the enterpprises going. They tried to get all of us enlisted in that.

There is no documented proof that any of the Oregon writers were communists. One of the supervisors sent by Washington to arbitrate the dispute, dismissed Powers' accusations by writing Alsberg, "the Reds are not even Pinks; they are green and blue; and loyal, fine people." 53 
Yet, it is important to note that Powers' charges of agitation cannot be totally ignored. Prior to the threatened strike, there seemed to be little open criticism of Powers. Maurice Howe, regional supervisor of the Federal Writers' Project, was somewhat taken back by the vehement display of feeling by the workers threatening to strike, something which he had not seen on previous visits to Oregon. Some of the writers claimed that they had been forced to be quiet about their differences prior to the threatened strike. Howe still believed that "many of the allegations [about Powers] were very flimsy and in all fairness should be thrown out of court, so to speak." He also suggested that many of the writers were using a "veneer" of "seeming sincerity" to undermine Powers' reputation. Howe cautioned that many of the statements made by the workers were influenced by their "physical, mental, and financial conditions." He pointed to one strike leader who had "a wife, two small children, another in route, and ... suffers from stomach ulcers. A labor leader in this condition might possibly not be temperate in his statements. "54 Whether the writers' allegations stemmed from communist influence, ego conflicts amongst writers, or a more traditional managementlabor dispute, they threatened the project in Oregon.

Compounding the problem was Powers' sudden support for the position of Minnie Lee. Powers had hired Lee in the spring of 1937 to be Assistant State Supervisor of the Historical Records Survey at $\$ 125$ a month. In rebutting the writers' charges, Powers stated that he planned to stand by Lee to the end and put up a bitter fight for her retention. This unnecessary defense of Lee embarrassed Powers' supervisors, who discussed his personal relationship with Lee at some length in their deliberations. ${ }^{55}$ 
Three of the key figures in the negotations between Powers and his staff arrived in Portland in late September, 1937, ostensibly to greet Roosevelt on his visit to the area. The three were Maurice Howe, Regional Supervisor of the Federal Writers' Project; Mary H. Isham, the Regional Womens' and Professional Project Supervisor; and J. M. Scammell, the acting Historical Records Survey Field Supervisor. Scammell assumed the role as major investigator of the charges levelled against Powers. Also involved in the negotiations were Gladys Everett, Oregon State Director of Womens' and Professional Project; and E. J. Griffith, State Administrator of the Works Progress Administration. ${ }^{56}$ Upon conferring with both sides, Howe and Scammell were able to convince the workers to postpone the strike even though no promises were made to the writers. Howe busied himself with investigating the Berelson affair and the dismissal of Churchi11. On September 29, 1939, two days after the threatened strike, Dr. Luther Evans, Federal Director of the Historical Records Survey, authorized the dismissal of Dr. Berelson, who was being paid out of Historical Records Survey funds. This paved the way for the retention of Claire Churchill.

Some discussion was given to the prospects of this national level interference precipitating Powers' resignation. Howe expressed doubts that Powers would resign and argued that even if he did, it would not affect the guide work because he was confident that Churchill, Vern Bright, the State Editor of the Guide, and "the good staff" could finish the work. 57 On October 1, 1937, Powers finally met with three workers and was formally presented with the grievances. The three asked for Powers' 
resignation. Powers was apparently prepared for the visit and showed willingness to make compromises. He suggested that he give up his role as Director of the Historical Records Survey to Claire Churchill, thus retaining her. His position as Director of the Oregon Writers' Project would be reduced to six days per month. Minnie Lee would shift from assistant director of the Historical Records Survey to be his assistant on the Writers' Project. He also proposed to move the Project from the Myler Building to the Oregon Building, where his University of Oregon offices were, so he could offer direct supervision of the Project. Howe telegraphed Alsberg that the proposal had both Griffith's and his approval. 58 Howe left Portland without waiting for a response from Alsberg, assuming that a workable compromise had been reached.

Scammell continued to be unhappy with the situation in Portland and informed Alsberg of this on October 2, 1937. He seemed to feel that Churchill should remain working on the Guide, and that Courtland Matthews, also cut because he was non-certified, should be returned to the Project to supervise the Historical Records Survey. ${ }^{59}$ Alsberg wired back: "Powers' services no longer desired under any circumstances." Alsberg also expressed the desire to terminate Lee and Dr. Evans concurred with Alsberg's decision. 60

For the next two days a flurry of activities and meetings occurred with recommendations of proposed organizational rearrangements and discussions of how best to ease Powers out. ${ }^{61}$ on 0ctober 4 , it became apparent that a move had to be made to remove Powers. Since October 1, Powers had assumed that his plan for reorganization had been approved 
and on 0ctober 4, he appeared in the office, started to give the staff a pep talk, and prepared to send them out on assignments. He then proceeded to remove Project materials from the office. When informed of Powers' actions, Scammell commented that "the man appears to be so inflated with his own ego that he is still unable to conceive of any possibility of his removal." Scammell went to Powers office to confront him. He later wired Evans and Alsberg that:

It was an odd meeting; for after the greetings he stared into my eyes and I stared back until he stopped. He was looking there for information, I suppose. Then he began to discuss his plans. - . I merely warned him against making definite plans when the proposed changes had not yet been approved; but he assumed confidently that they would be approved and launched upon a lengthy discourse why it was necessary to make haste.

Meanwhile, Miss Lee was sober and apprehensive and watched me like a hawk; and I am of the opinion that she is aware that all is not yet well; but that being Powers' simply will not believe anything unpleasant.

I am beginning now to feel sorry for them both; for he is not as jaunty as he was; while she is only 故e ghost of the bright and attractive woman of this summer.

Griffith, once convinced by Scammell and Everett that releasing Powers was not capitulating to the union, agreed to ask for Powers' resignation. Scammell suggested that getting Powers to resign would not be difficult if he would play upon Powers in the following ways:

One is his unquenchable thirst for esteem and adulation, and the consequent wounding of his pride. The other was his ferocious defens $8_{3}$ of Miss Lee and his determination to shield her at any cost. 
On October 5, Griffith met with Powers, who agreed to resign quietly along with Lee. There is no indication that Griffith had to resort to any of the persuasive techniques suggested by Scammell. T. J. Edmonds, a special assistant for Women's and Professional Project in Oregon, was appointed acting director of the Oregon Writers' Project at $\$ 325$ a month. Claire Churchill was made assistant supervisor of the State Guide at a monthly salary of $\$ 125$. Vern Bright was retained at $\$ 94.80$ a month as State Editor of the Guide. 64

Powers had been with the Oregon Writers' Project for two years and while his most important task, the Oregon Guide, remained incomplete, he had managed successfully to complete other publications. Included in these were The Flax Industry of Oregon, Mt. Hood Timberline Lodge, Oregon Airports, Dr. John McLoughlin, and Builders of Timberline Lodge. Unfortunately, however, none of these books had been authorized by the national office even though they had all been done on Project time. 65 Powers also kept a rather large number of people employed even though Oregon's relief role did not always warrant these high numbers.

On the whole, Powers was not the most effective administrator. He did not efficiently use the time allotted for his job to provide proper supervision of his staff. Yet, the very activities as Extension Head for the University of Oregon that deterred his effectiveness on the Project, also helped the program. Powers' knowledge and contacts around the State brought the Project strong public support, something it often lacked in other states. ${ }^{66}$ Furthermore, while both his unauthorized 
publications and large staff ran contrary to the rules and regulations of the national program, they perhaps met the original intent of giving unemployed writers a chance to write. 


\section{FOOTNOTES}

1. Ronald Taber, "The Federal Writers' Project in the Pacific Northwest:

A Case Study". (Ph.D. dissertation, Washington State University, 1969), p. 86. E. J. Griffith was very supportive of the Oregon Writers' Project from its inception and cooperated closely with the state directors of the Writers' Project throughout the program's duration. The idea for one of the publications of the Project Mount Hood: A Guide came from Griffith and his wife.

2. George Cronyn, Associate Director Federal Writers' Project, to E. J. Griffith, Oregon State Administrator of the W.P.A., (telegram) 0ct. 1, 1935. Unless specifically cited otherwise the documents cited herein are held in Record Group 69; central correspondence files of the Works Project Administration, Records of the Federal Writers Project, Records Relating to the WPA Writers Project in Oregon, National Archives (Washington, D. C.).

3. Howard McKinley Corning, "All the Words on the Pages, I: H. L. Davis," in Oregon Historical Quarterly, LXXIII, No. 4 (December, 1972), p.p. 312-313.

4. Griffith to Cronyn (telegram), Oct. 2, 1935.

5. Corning, p. 324 .

6. Jacob Baker, an assistant director of the Federal Writer's Project, to Griffith, Oct. 10, 1935.

7. Alfred Powers, History of Oregon Literature (Portland, Oregon, 1935).

8. Baker to Griffith, Oct. 10, 1935.

9. J. M. Scammell, Acting Federal Writers' Project supervisor, to Griffith, Oct. 4, 1937.

10. Alfred Powers, State Director Oregon Writers' Project, to Henry Alsberg, National Director of Federal Writers' Project (telegram), 0ct. 30, 1935.

11. Powers to Alsberg (telegram), Oct. 29, 1935.

12. Griffith to Alsberg (telegram), undated.

13. Alsberg to Griffith, Nov. 9, 1935.

14. Powers to Alsberg, Nov. 12, 1935. 
15. Griffith to Alsberg (telegram), Nov. 20, 1935.

16. Alsberg to Powers (telegram), Jan. 31, 1936.

17. Alsberg to Maurice Howe, Regional Supervisor Federal Writers' Project (telegram), Jan. 30, 1936.

18. Taber, p. 51 .

19 Powers to Alsberg, Aug. 20, 1936. Taber, p. 94.

20. Powers to Alsberg, Aug. 20, 1936.

21. Interview with Alfred Powers, June 7, 1973. Taber, p. 92. Taber notes that while three of the editors were qualified for certification they refused to do so in the belief that it would "jeopardise their future careers."

22. Interview with Alfred Powers, June 7, 1973.

23. Powers to Alsberg, Aug. 20, 1936. Griffith to Alsberg, July 29, 1937.

24. Powers to Alsberg, Aug. 20, 1036.

25. Untitled Document, Nov. 7, 1935.

26. Untitled interview by Sara B. Wrenn in the Records of the Works Project

Administration related to the Oregon Federal Writer's Project, Oregon

State Archives (Salem, Oregon), undated, pp 6-7.

27. Ibid., p. 7 .

28. Ibid., p. 8 .

29. Interview with Alfred Powers, June 7, 1973.

30. Interview with Alfred Powers, June 7, 1973.

31. Interview with Alfred Powers, June 7, 1973.

32. Cronyn to Powers, June 24, 1937.

33. Katherine Kellock, a Federal Writers' Project editor, to Alsberg, July $7,1936$. 
34. Powers to Cronyn, July 10, 1936.

35. Cronyn to Powers, 0ct. 5, 1937.

36. Cronyn to Powers, 0ct. 27, 1936.

37. Interview with Powers, June $7,1973$.

38. Kellock to Frank Wells, Federal Writers' Project Field Supervisor, Nov. $6,1936$.

39. Alsberg to Wells, Nov. 9, 1936.

40. Wells to Alsberg, Nov. 16, 1936.

41. Editorial Report on Oregon State Copy, April 26, 1937.

42. Cronyn to Powers, June 14, 1937.

43. Cronyn to Powers, Sept. 28, 1937.

44. Cronyn to Powers, June 26, 1937.

45. Cronyn to Alsberg, Sept. 29, 1937. Powers to Cronyn, June 25, 1937.

46. Howe to Alsberg, Sept. 27, 1937. Howe to Alsberg (telegram), Sept. 28, 1937. Howe to Alsberg (telegram), Sept. 29, 1937. Howe to Al sberg (telegram), Sept. 30, 1937. Howe to Al sberg (telegram), Oct. 1, 1937. Howe to Alsberg, Oct. 4, 1937. Scammell to Griffith (memo), oct. 4, 1937.

47. Powers to Cronyn June 25, 1937. Scammell to Alsberg, Oct. 4, 1937.

48. Howe to Alsberg, Sept. 27, 1937.

49. Howe to Alsberg, Sept. 29, 1937. Howe to Alsberg, Sept. 29, 1937.

50. Interview with Powers, June 7, 1973. Howe to Alsberg, Oct. 4, 1937.

51. Interview with Powers, June 7, 1973. Powers did not name the "Communist Seven" directly, but instead alluded to them by the job position. Sherriff and Wilmont were obvious because they were head of the union. The other five most likely were Steward Holbrook, Claire Churchill, Kenneth Fitzgerald, Margaret Clarke and a Mr. Cookston. 
52. Interview with Howard Mckinley Corning, April 6, 1973.

53. Scammell to Alsberg, 0ct. 2, 1937.

54. Howe to Alsberg, 0ct. 4, 1937.

55. Scammell to Alsberg and Luther Evans, National Director of Historical Records Survey. 0ct. 4, 1937. It should be reminded here that Alfred Powers was also the State Director of the Historical Records Survey, the research arm of the Writers' Project. This dual directorship meant that all problems concerning this incident needed to be dealt with by the administrative staffs of both the Writers' Project and the Historical Records Survey.

56. Howe to Alsberg (telegram), Sept. 28, 1937. Howe to Alsberg, oct. 4, 1937.

57. Howe to Alsberg (telegram), Sept. 28, 1937.

58. Howe to Alsberg (telegram), Oct. 1, 1937.

59. Scammell to Alsberg (telegram), Oct. 2, 1937.

60. Alsberg to Scammell (telegram), Oct. 2, 1937.

61. Scammell to Alsberg (telegram), Oct. 3, 1937. Howe to Alsberg (telegram), Oct. 4, 1937. Scammell to Alsberg (telegram), Oct. 4, 1937. Scammel1 to Griffith (memo), Oct. 4, 1937.

62. Scammell to Alsberg and Evans (telegram), Oct. 4, 1937.

63. Scammell to Alsberg and Evans (telegram), Oct. 4, 1937.

64. Scammell to A7 sberg (telegram), Oct. 5, 1937. Mary H. Isham, Regional Women's and Professional Project Supervisor, to Evans (telegram) oct. $6,1937$.

65. Powers to Alsberg, Aug. 20, 1936. Griffith to Alsberg, July 29, 1937. 66. Howe to Reed Harris, an assistant director of Federal Writers' Project, 0ct. 19, 1937. 


\section{CHAPTER IV}

\section{OREGON 1937-1942}

Henry Alsberg's first choice for director of the Oregon Writers' Project was Claire Churchill, but Churchill's appointment was vetoed by Alfred Powers. Powers claimed that Churchill lacked administrative skills, but more likely, the outgoing director was attempting to save face by exerting some measure of power over a former adversary. ${ }^{1}$ In order to placate Powers, state WPA Administrator E. J. Griffith appointed J. V. Edmonds as acting director, with the assumption that Churchill would receive the job in a few months. That change never occurred. ${ }^{2}$ Edmonds, a journalist by trade, and an Oregon WPA assistant for Women's and Professional Projects, soon showed himself to be a highily thorough and business-like director. He won popular staff support, and his strong political skills enabled the new director to deal with the many. WPA agencies. ${ }^{3}$ Not only did Edmonds remain as director of the Oregon program through 1942, but Alsberg also used him to reorganize the Washington, Nevada, and Northern California Writers' Projects after local problems threatened to dismantle programs in those states. 4

Edmonds' most pressing tasks were to reestablish morale among the Oregon staff and to complete the state guide. But he soon discovered that raising morale was simple in comparison to completing the Oregon Guide. Criticism from Washington continued over the editing of the Guide materials, while the Oregon staff persisted in condemning national. interference with content and constantly changing guidelines. 
Three specific areas that caused major problems for Oregon were the city essays, the topical essays, and the tour guides. Washington criticized the initial city essays as "well written," but felt they were too long because of the heavy use of adjectives. Oregon was ordered to cut the material. New efforts were then chastized for having "lost considerable vigor" and Oregon was told to return "some of the more interesting material," from the original version. ${ }^{5}$. The Washington office was not hesitant to offer their own ideas of what was important in Oregon cities. The city of Portland's materials were returned with a note by Alsberg that the Rose Festival should be played up. This lifelong easterner went on to say:

Portland citizens cherish their roses and nowhere do these flowers grow more abundantly or more beautifully. In June, the city glows with every variety of roses but the flower gardens are a feast for horticulturists and are the pride of Portlanders. The well tended lawns are strattled with Oregon Grape, ornamental shrubs, and conifers. In vacant lots, hilltops, and parks one is conscious that the site of the city was originally covered with conifer forests and their descendants tend to return at the slightest opportunity.

A few months later the Portland material was again returned to Oregon because it mentioned Chinatown but listed no Japanese points of interest. The Oregonians were also reminded to mention that there was a museum in City Hall, also one at the University of Oregon Medical Center and that William Hume, father of the salmon canning industry, was buried at Lone Fir Cemetery. ${ }^{7}$

Portland was not the only Oregon city of which the national editors were willing to offer their knowledge. Concerning the Baker material, the national office wrote that "we do not feel that the peculiar quality of Baker has been captured in this copy." The local writers 
were informed that Baker was the easternmost city of the state surrounded by the Rocky Mountain system with "vast areas inhabited chiefly by gophers and rattlesnakes." 8 Arguments over who knew most about Oregon cities continued until late 1939 when all the city essays were finally completed. $^{9}$

In the area of topical essays, the literary essay garnered its share of reproval from Washington. Interestingly, this essay was first done under Alfred Powers, who had written a guide to Oregon literary figures, but Washington returned the manuscript because some of the more important writers and their writings were neglected. 10 These essays were assigned to Howard McKinley Corning who agreed with Washington that they did not do full justice to current Oregon writers and totally neglected Oregon poets. ${ }^{11}$ Even though Corning conferred with Washington on the issue, his manuscript fared no better with the central editors than the previous one. Washington returned the material with the same complaints as before and ordered him to try writing it again. ${ }^{12}$

The history essay, another topical essay, concerned the Washington officials because national editors objected to what they believed to be biased and prejudicial statements. Edmonds' response showed his astute perceptions of the political realities of writing by commenting:

Whatever bias may appear in the Oregon copy is a result of a careful consideration of the fact that the state is sponsoring the Oregon Guide and a realization that no adverse criticism will come sooner than that which arises from the pioneer and their descendants.

Alsberg quickly responded to Edmonds' comments by suggesting "that the most factful way of handling such matters [history] is to present all 
the facts in a detached manner without editorializing or interpreting. "14 Oregon must have met this criticism, since no more was heard on the subject of history writing.

Out of all the writings, the tour essays gave Oregon the most problems. The design of the tour guides themselves caused some of the trouble. The tours followed a major road or highway and required writers to produce short, crisp, colorful descriptions of all points of interest, cities, towns, major geological formations, industries, and historical sites with accurate mileage charts in an easily readable style for the traveling motorist. ${ }^{15}$ In November 1937, a tour mileage report filed with Washington noted that the obvious problem of writing tours was the "difficulty of reconciling considerations of desirability of retaining literary style and of adding or expanding items with that of limiting wordage so as to meet financial and mechanical requirements of the book."16

Time and time again tours were rejected by the national editors. Washington's primary concern was that the tours were "terribly monotonous," lacked "human interest," and used too much verbiage, making it read like "a 1iterary masterpiece."17 Edmonds shrank from the offer by the Washington editors to write the tours for Oregon because that would have had a demoralizing effect on his staff. Instead, he replaced the state tour editor, Ada Hedges, with Vern Bright. ${ }^{18}$ Bright, according to one writer, was selected because he was able to "edit in and edit out with the best of them"19 but Bright's standards did not match up to those required by Washington. Though he and the staff worked diligently to rewrite the tours in record time, 20 when the national office got around 
to looking at them five months later, they were horrified to find them 40,000 words too long. ${ }^{21}$ The national editors returned the tours to Oregon to be revised two more times before they were finally accepted. ${ }^{22}$ The Oregon problem with the tours was not totally the fault of poor and slow writing and editing in Portland. Delays in finishing tours could be faulted to Washington because of the time manuscripts spent laying on desks in the central offices before they were finally edited. During this period of time, editorial rules on how to write tours were constantly changing. As a result, a tour sent to Washington correctly written often was chastized for being improperly written because guidelines had changed by the time Washington read the manuscript. ${ }^{23}$

Howard McKinley Corning, a unit supervisor for the Project, remembered this period of writing and rewriting materials as "intense." He explained that many people were field workers who were assigned to work from principal county seats. Initially, most people were "out in the field" but as material came in and was assembled, many of these people were brought back to Portland. All the material that came in had to be typed first and then sorted into file cases. Corning and others were given an assignment and went through the file cases to get much of their writing material. This type of work kept a dozen or more people busy at all times. The writer then returned to the field to follow-up on facts or dates, wrote the article or tour, and forwarded it to Vern Bright for editing. Bright then sent it on to Washington. For Corning, as for others, Washington's constant rewriting could be frustrating. He claimed "orders were changed in midstream. . . things were 
changed suddeniy, countermanded. It would affect a dozen people. . and sometimes the whole project would be affected." 24

The Oregon guide finally was ready for press by 1ate 1939, but two problems remained to be settled before the book could be published. First, the book did not have a title. Second, a decision had to be made on who would publish it. For the title, Alsberg originally suggested, Oregon: From Sea to Timberline. ${ }^{25}$ Griffith pointed out that this title would be inaccurate since that area of 1 and, from the sea to the timberline, only covered part of the State of Oregon. ${ }^{26}$ The title Oregon: End of the Trail was finally chosen after it was recommended by J. D. Newson, Alsberg's replacement as Director of the Federal Writers' Project. 27

The selection of a printer was not as easy as the selection of the title. The Oregon State Legislature had appropriated $\$ 3,000$ in 1937 for publication of the Guide. Because of this appropriation, it was assumed that the state printer would print the Guide. ${ }^{28}$ The national office, however, insisted that a national printer do the Guide in order to facilitate better distribution. ${ }^{29}$ Griffith ultimately was able to convince the state to allow a Portland firm to print the book. ${ }^{30}$ This still did not please Alsberg who complained quite emphatically to Claire Lansing, the Federal Writers' Project field supervisor, that:

We do not want the book published in Oregon. There are several reasons for this. One, is that printers are seldom publishers, and therefore lack the equipment and sales forces it takes to distribute the book nationally. Since our books are of national interest, we want as wide a distribution as possible. Also, we find from experience that few state printers or small publishing houses are able to put out as affractive a book as a national publisher at the same low cost. 
The argument over who would publish the book went on for a year. Finally, in 1939, in an about-face, Alsberg requested that Binford and Mort of Portland, who were associated with an east coast publisher, be named to publish the book. ${ }^{32}$ Binford and Mort accepted the offer and the book was published in Portland. 33

Oregon: End of the Trail was published in May $1940^{34}$ with a laudatory forward by Governor Charles A. Sprague. The Guide was divided into four parts. The first section, called "Past and Present," contained essays on Oregon's history, foods, theater, architecture, and other general topics of interest. The second segment, "Cities and Towns," covered in six to ten pages each, ten cities in Oregon. Part three included the troublesome tours. There were ten main tours plus three special tours of national forests and parks. The last section contained the appendices. 35

Reviews of Oregon: End of the Trail, primarily written by members or ex-members of the Project, were needless to say, quite glowing. The Oregon Sunday Journal wrote that "while much of the book is devoted to dry facts of interest only to those particularly concerned in the topics discussed, many pages are filled with entertainingly presented articles. 36 The reviewer for the Eugene Daily News wrote that the "essays are too short, but like a sermon, that is a good fault for an essay." He noted that the tours were factual with mileage and statistics but avoided dullness and were filled with frequently interesting bits of history. He believed that the city section "should please the most meticulous Chamber of Commerce." 37 Stewart H. Holbrook, a former state editor of 
the Guide, wrote for the New York Herald Times that he "could not find a line that any reasonable person could object to." While noting that the few pictures suffered from poor reproduction, he stated that the book was excellent, and acknowledged that "not before has so much about the Webfoot State been put between the covers of one book." 38

The Oregon Guide had taken more than four years work by the State Writers' Project despite the fact that twenty to forty people had labored on the Guide between 1935 and 1939. ${ }^{39}$ Part of the reason for the slow pace of the work was the continuation of Powers' policy of using Project employees on unauthorized publications. In fact, the national office followed Powers' example on this issue, and began to encourage state projects to take on a diversity of writing activities. 40 In addition, between 1938 and 1940, Washington permitted the Project to loan writers on a full-time basis to other agencies, which in Oregon included the U. S. Department of Agriculture, Biological Survey, the Oregon State Planning Board, and the WPA state offices. ${ }^{41}$ All of this time spent on compiling city histories, pamphlets and miscellaneous guides did not please T. J. Edmonds. In commenting on the Project, Edmonds wrote that "books undertaken by Writers Projects should place more emphasis on social conditions and leave the historical abstractions to be exhumed by the academic grave-diggers." Aware that the federal office chose guidebooks and other innocuous projects because of their non-political nature, Edmonds continued:

Certainly no matter what we write, our enemies are going to blast us anyway. We might as well have the game as the name. . I would like to read as a part of the program, books that describe the conditions under which contemporary Americans live. 
Included in possible story topics, Edmonds suggested people on relief, lives of indigent Americans, migratory workers, WPA writers, and lives of ordinary Americans surviving in the depression. Mr. Edmonds ended his comments by castigating current writing assignments. "Let the Chamber of Commerce," he wrote,

cover their own dunghills with rosewater, and show life as it is, instead of a collotype of postal card with a pretty girl and a sleek automobile on everybody's doorstep, and a luxury lodge just sixty miles from everybody's backyard. I have the utmost respect for the theory of the writers' project, but I don't believe that everything we have done so far (the Guide excepted) amounts to a patch on Mr. Roosevelt's oldest pair of pants, and I would like to see us 'go to town' where the sweat and smoke and strain is, and let the tourists fall off Mount Hood's trails without any help from us.

Edmonds reference to allowing tourists to fall off Mount Hood's trails stems from the other major publication credited to the Oregon Writers' Project. In May, 1939, the Mount Hood Development Association asked the Writers' Project to develop a 55,000 word Mount Hood Guide for its August Paul Bunyan festival. Permission was granted and workers quickly set about writing a Guide. ${ }^{43}$ By July, the original manuscript was returned from Washington. Alsberg faulted the copy because it sounded more like "a semi-scholarly treatise" than a recreation guide, 44 and because it lacked that "rare sense of humor. . . that Oregonians have." 45 The book was given to Vern Bright and Howard McKinley Corning who rewrote it following the example of the Death Valley Guide. ${ }^{46}$ Passing the August deadline for the Paul Bunyan festival, the book had to be changed because of possible plagarism due to its similarity to Fred McNeil's Wy'East. ${ }^{47}$ By the spring of 1940, the Guide was ready for publication. ${ }^{48}$ The 132-page book went on sale at a cost of $\$ 1.50$ in May 1940. It was published by Duell, Sloan, and Pierce of New York. ${ }^{49}$ 
The extent of other writing activities may be seen in a work chart for this period which showed three people working on one-act plays, one on an almanac, five on folklore, two on social ethnic studies, two on materials for the Portland Water Supply, one on radio material, and four working in the general category of information.

In 1938, the project published studies entitled "Portland Fire Alarm System" and "Fire Prevention in Portland." They also completed twenty-six radio scripts on Oregon historical subjects and issued the first of over fifty bulletins of a series called "Oregon Oddities." These bulletins continued until 1940 and covered various topics of interest about Oregon's past such as "Oregon Firsts," "Ghost Towns," and "Early Oregon Farm Life." 50 The following year, the project spent an average of 111 person-hours per month to produce items such as a radio series based on Oregon Oddities, a second edition of $\mathrm{Flax}$ in Oregon, short tracts on the Oregon Trail and Timberline Lodge, a series of tales called "Webfoot Whoppers," and a weekly article of historical interest for the Oregonian "Sunday Feature." That same year, the project also provided radio scripts for various programs of public interest for KEX and the radio station at Benson Polytech.

The project continued its active schedule in 1940 with the Oregon Almanac, Builders of Timberl ine Lodge, Toy and Joy Makers, Salem Centennial Project, and Pioneer Characters and Costumes. ${ }^{51}$ When the project ended two years later, Oregon writers had produced over forty of these smaller studies of under 8,000 words each; ${ }^{52}$ and dozens of other projects which were begun and never completed. A 1941 report 
listed fifty projects that were currently in process. of these, thirteen were completed, nine were suspended, thirteen had nothing done on them, and the rest were in various stages of completion. 53 Some of these uncompleted undertakings were completed after the project closed. Included in these were three books Willamette Landings, The Dictionary of Oregon History, and The History of Milwaukie, Oregon. 54

While these diverse activities were attacked by Edmonds and others as a questionable usage of time, they may have served a very real purpose. Take for example the problem noted earlier with the tour materials for the Oregon Guide. On one occasion those materials spent five months in Washington waiting to be edited. During this time, those who worked on the tours needed to be employed el sewhere. These short activities could be used to fill such free time. Unfortunately, these publications were not of great literary note, but they did fulfill three major criteria of the project in that they avoided political controversy, had local sponsorship, and kept unemployed writers employed.

Between 1940 to 1942, a period in which a growing war economy stimulated America's marketplace, the Writers' Project lost many of its better writers to war activities. ${ }^{55}$ Those remaining became a part of the war effort as the Writers' Project became practically an informational arm of the armed services. Edmonds had foreseen this in 1939 in his comments on the program to J. D. Newson. He wrote that "while it may be hazardous to elaborate on this idea, the outbreak of the war and the possibility of our own participation raises the implication of the use of writers to inform the public." 56 As with Powers earlier usage of workers for non-guide-activities, Oregon once again pioneered in a 
non-project activity with almost total devotion of time and energies to war propaganda. This was an activity the national office finally sanctioned in January of 1942 for all state projects. 57

One of the first undertakings of this type in Oregon was a brochure readied in June 1940 on the state's wartime resources. ${ }^{58}$ The national office liked the brochure so much that it suggested that all states do one. ${ }^{59}$ But Washington soon discovered to their chagrin, that the publication was little more than a Chamber of Commerce sales job for Oregon. The document suggested that Oregon become the wartime industrial center of the United States because the east was vulnerable to attack from Germany. 60

Another major activity during this time period involved writing radio scripts and press releases for the Army and Navy. Among these programs was the successful "Soldiers of the Air." Claire Churchill was the major writer for this radio series. The recruiting office in Portland complemented her on the show because their "enlistment considerably exceeded all past records. . and we're sure that the Oregon Writers' Project had played a very important part in this." 61 Later, the recruiting office wrote Churchill to inform her that other stations around the country were interested in the program. ${ }^{62}$ This lead to a second series of the program and to three other series--"Keep 'Em Flying" in August 1941, "The Dinners' On You" in September 1941, and "Air Base Skits" in late 1941.63 Besides the radio show, the writers prepared a series of short feature stories entitled "Ten - S - K - U - N!" as well as numerous press releases and feature stories about enlistments and war activities. 64 
War activity provoked a highly enthusiastic Edmonds to proclaim in his monthly report of May 1941 that

The Writers' Project practically became an adjunct to the United States Army Recruiting Service during the month. Certain activities upon which there is no 'deadline' were temporarily deferred in order to further the cause of Defense at the request of the military authorities, and more than half of the writing personnel were assigned to this service. The value of it in the way of increasing enlistments is testified to by letters previously filed with you from Captain Kirk. The Project feels that it is helping in a real sense in winning, if not the war, at least the enterprise of National Defense. . A All this is very gratifying, as it makes us feel that the Writers' Project has come into its owp and demonstrated its usefulness in time of capital emergency.

The national office soon tried to put a damper on Edmonds' enthusiasm by responding that

While this activity is unquestionably one of national service, we strongly advise the Oregon Writers' Project, not to undertake so much work along this line that other activities, already sponsored and contracted for, be jeopardized. According to our records, the Oregon Writers have numerous activities underway, some that were begun a long time ago, and, in many cases, there seems to have been little or no progress made. It is highly important that these sponsored activities be speeded up.

The Oregon office ignored the advice. In July 1941, the Oregon staff was cut from fifty to twenty-five 67 The remaining staff spent practically all of their time on war propaganda. In December 1942, three months before the national writers' office was closed, the records of the Oregon Writers' Project were deposited in the state library at Salem ${ }^{68}$ ending the federal government's longest sponsorship of writers in the history of the State of Oregon. 


\section{FOOTNOTES}

1. Interview with Alfred Powers, June 7, 1973.

2. J. M. Scammell, Acting Historical Research Survey Field Supervisor, to Henry Alsberg, National Director of the Federal Writers' Project, Oct. 5, 1937. Reed Harris, an assistant director of the Federal Writers' Project to Mrs. Hawkins, Financial Officer of the WPA, Oct. 11, 1937. Maurice Howe, Regional Supervisor of the Federal Writers Project, to Alsberg Dec. 2, 1937. Unless specifically cited otherwise the documents cited herein are held in Record Group 69: central correspondence files of the Works Projects Administration, Records of the Federal Writers Project, Records of the Central Office, National Archives (Washington, D.C.I.

3. Scammell to Alsberg and Luther Evans, National Director of the Historical Records Survey, Oct. 5, 1937. Scammell to Alsberg and Evans, 0ct. 7, 1937. Mary H. Isham, Regional Supervisor of Women's and Professional Services, to Ellen D. Woodward, National Director of Women's and Professional Services, Nov. 17, 1937. Howe to Alsberg Dec. 2, 1937. Isham to Woodward, Dec. 6, 1937.

4. Alsberg to E. J. Griffith, Oregon State Administrator of the WPA, Nov. 4, 1939. Florence Kerr, Federal Writers' Project editor, to Griffith, May 22, 1939. T. J. Edmonds, State Director Oregon Writers' Project to J. D. Newson, National Director Federal Writers'Project, Sept. 6, 1939.

5. George Cronyn, Associate Federal Writers' Project Director, to Edmonds, Oct. 13, 1937.

6. Alsberg to Edmonds, Dec. 27, 1937.

7. "Washington, D.C. Research Information," Feb. 10, 1938.

8. Alsberg to Edmonds, Jan. 28, 1938.

9. Howe to Griffith, Dec. 8, 1939.

10. Alsberg to Edmonds, Dec. 6, 1937.

11. Howard McKinley Corning, Writer for the Oregon Writers' Project, to Alsberg, July, 1938.

12. Alsberg to Griffith, Sept. 10, 1938.

13. Griffith to Alsberg, April 7, 1939. 
14. Alsberg to Griffith, April 13, 1939.

15. To appreciate the difficulty of tour writing it is worthwhile to look at the tour section of Workers of the Writers' Project of the Work Project Administration in Oregon, Oregon: End of the Trail (Portland, 1940) pp. 249-511.

16. Tour Mileage Report, Nov. 19, 1937.

17. Claire Lansing, Federal Writers' Project Field Supervisor, to Alsberg, Feb. 9, 1938. Alsberg to Edmonds April 13, 1938. Alsberg to Edmonds, Sept. 12, 1938.

18. Alsberg to Griffith, July 27, 1938. Edmonds to Alsberg, Sept. 2, 1938. Edmonds to Alsberg, July 12, 1938.

19. Interview with Howard Mckinley Corning, Apri1 6, 1973.

20. Griffith to Alsberg, Nov. 1, 1938.

21. Alsberg to Griffith, Nov. 23, 1938.

22. Howe to Griffith, Dec. 6, 1939.

23. Kerr to Edmonds, June 15, 1939. Edmonds to Newson, Sept. 6, 1939.

24. Interview with Howard McKinley Corning, April 6, 1973.

25. Alsberg to Griffith, June 14, 1938.

26. Griffith to Kerr, May 16, 1939.

27. Newson to Griffith, Jan. 24, 1940.

28. Powers to Cronyn, June 25, 1937.

29. Alsberg to Powers, July 1, 1937. Alsberg to Griffith, Dec. 10, 1937.

30. Griffith to Alsberg, Jan. 14, 1938.

31. Alsberg to Lansing, Feb. 1, 1938.

32. Alsberg to Griffith, Feb. 28, 1939.

33. Griffith to Alsberg, Apri1 26, 1939.

34. Publisher's Report, July 15, 1940.

35. Workers of the Writers Program of the Works Progress Administration in Oregon, Oregon: End of the Trail (Portland, 1940). 
36. "Oregon End of the Trail," The Oregon Sunday Journal, July 14, 1940. This article was deposited in the records of the Works Project Administration Related to the Oregon Federal Writers' Project Oregon State Archives (Salem, Oregon).

37. Marche I. Landley "Tales of Oregon Told in New 'End of Trail, '" Eugene Daily News, August 11, 1940. Ibid.

38. Stewart H. Holbrook, "A State of Contrasts," New York Herald Iribune, Sept. 21, 1940. Ibid.

39. Griffith to Alsberg, March 9, 1936. Alsberg to Powers (telegram), April 28, 1936, Powers to Alsberg, July 23, 1936. Labor Report, Jan 31, 1938. Labor Report Jan. 31, 1939. It should be noted that these estimates include only those directly involved with the Guide. There were other employees working on non-guide activites and the Historical Record Survey. If these people were counted, the number of employees would be about twice as large.

40. Alsberg to Griffith, June 10, 1938.

41. Griffith to Alsberg, July 29, 1938.

42. Edmonds to Newson, Sept. 6, 1939.

43. Griffith to Kerr, May 17, 1939.

44. Alsberg to Griffith, Juty 6, 1939.

45. Alsberg to Griffith, July 10, 1939.

46. Griffith to Kerr, Aug. 2, 1939.

47. Newson to Griffith, Nov. 22, 1939.

- 48. Newson to Griffith, Jan. 19, 1940.

49. "Publishers Report, July 15, 1940.

50. Work Chart for Oregon Writers' Project, undated.

51. Oregon WPA Writers' Project, "Publications Sponsored and Completed," undated.

52. Griffith to Kerr, Jan. 14, 1942.

53. Oregon Writers' Project, "Monthly Publications Report," Jan. 28, 1941. 
54. Howard McKinley Corning, Will amette Landings (Portland, Oregon, 1947). Howard McKinl dy Corning (ed.), Dictionary of Oregon History (Portland, Oregon, 1956). Charles 01 af 01 son, The History of Milwaukie Oregon (Milwaukie, Oregon, 1965).

55. Interview with Howard Mckinley Corning, April 1, 1973.

56. Edmonds to Newson, Sept. 6, 1939.

57. Newson to Griffith, Jan. 12, 1942. Newson to Griffith, Jan. 19, 1942.

58. Griffith to F. C. Harrington, National WPA Administrator, June 20, 1940 .

59. C. E. Triggs, Director of WPA Public Activities Program, to Newson, Aug. 15, 1940.

60. Triggs to Griffith, Oct. 18, 1940.

61. Weldon H. Kirk, Army Recruiting Office Director for Portland, Oregon, to Claire Churchi11, Writer Oregon Writers' Project, May 8, 1941.

62. Kirk to Churchill, May 23, 1941.

63. Gladys Everett, State Administrator of Women's and Professional Services, to Kerr, Aug. 6, 1941. Everett to Kerr, Aug. 25, 1941. Everett to Kerr, Sept. 29, 1941. Everett to Kerr, Dec. 8, 1941. Everett to Kerr, Oct. 22, 1941.

64. Griffith to Kerr, May 14, 1941.

65. Narrative Report, May 1941.

66. Kirk to Griffith May 20, 1941.

67. Narrative Report, July 1941.

68. Kerr to Harrison Devereaux, Oregon's new WPA administrator, Dec. 9, 1942. 


\section{CHAPTER $V$}

\section{CONCLUSIONS}

The Oregon Writers' Project lasted for seven years. During this time, thousands of person-hours and hundreds of thousands of dollars were invested in a program to put unemployed Oregon writers to work in their chosen field. In assessing the success of the project in Oregon, one must look at questions of personnel and administration and evaluate the Project's written accomplishments, as well as the severe criticism of the Writers' Project offered by Ronald Taber in his work The Federal Writers' Project: The Pacific Northwest. Finally, the program needs to be evaluated as to its validity as Government sponsorship of the arts.

Two major problems occurred in staffing the Writers' Project in Oregon and elsewhere. First, the national office failed to establish any criteria for what a writer was. Washington used the relief office's definition, which meant that anyone who had ever had his words in print could qualify for employment in the program. This inflated the roles of the unemployed writer with every type of imaginable hack, would-beauthor and letter-to-the-editor writer. These people diluted the quality of the program. Alfred Powers, the first director of the project in Oregon, willingly admitted that he had people who were totally incompetent in dealing with the written word. Fortunately for Powers, and later Edmonds, a place existed within the project to use many of these would be writers. Over half of the work of the project was spent in 
the field researching materials for the various publications. With training, many of these people were turned into adequate researchers and were kept busy combing through county records, visiting historical sites, interviewing pioneers, cataloging materials and other research related activities. While the problem of employing inexperienced writers was partially solved in this manner, the national office never dealt adequately with the definition of "a writer" and the program suffered for this oversight.

That Oregon found qualified writers at all seems to have been a minor feat. Oregon has never been considered the Mecca for the literary elite. Oregon's foremost writer of the thirties, H. L. Davis, for example, chose to spend much of his time away from the state. One of the best writers on the project, Stewart Holbrook, left after only nine months to move to New York so he could be closer to America's literary center. Yet, Oregon was able to find a relatively large number of writers who were well-educated and published. While none of these people could claim any great distinction in literary circles, they did have many years of experience as newspaper persons, small-time authors, and local poets. Ronald Tabor, even while claiming that the lack of qualified writers made it difficult to justify a writers program, had praise for the generally competent caliber of the Oregon staff. He noted that among the certified relief personnel there was a group of fourteen capable writers. Included in this group were eleven who had published books or articles, ten who had earned college degrees, five who had edited newspapers or journals, and four who had been college instructors. ${ }^{1}$ 
The other major personnel problem confronting the Oregon program was finding qualified writers who were certified or on relief. One must question if the state really needed such a project, since Oregon was unable to find enough qualified relief writers to meet the national office quotas. In hiring writers, the director of the Project could hire only one non-certified (non-relief) worker for every ten workers. Oregon frequently exceeded this limit and at one time had as many as $27 \%$ of its staff non-certified.

One must look at these figures realistically in deciding if a program was warranted in Oregon. In the first place, the non-relief limit was exceeded by only $27 \%$ for one month and this happened in a period when there was a large change-over in the certified staff. In fact, the program exceeded the $10 \%$ exemption on the average by only $5 \%$ or one to two people. This meant that in 1939, for example, while the program averaged fifty employees, six or seven were not on relief, while fortytwo or forty-three were on relief. Furthermore, non-certified personnel frequently were people who were certifiable but for reasons of pride or because of free-lance work, did not become certified. At one time, all three Project editors were qualified for certification, but refused to apply because they felt certification would "jeopardize their future careers." 2

Oregon was at fault in inflating the number of workers on the government roles. In all actuality, according to certification rules, Oregon had fewer unemployed writers than it claimed, and the Project frequently hired writers who were not legally eligible. One must question, however, if Oregon's approach to hiring was not more humane 
than that of the national office, especially in the recognition of the negative attitudes many people shared concerning relief.

Some of the Project's major problems came not in the area of personnel, but in program administration. While the Project was extremely fortunate that E. J. Griffith, the Works Progress Administration Director in Oregon, was supportive of the program and protected it from many of the administrative and political problems that stymied projects in other states, it still had difficulties with a major staff-director conflict, confused work priorities, and, most glaringly, poor relations with the national editors in Washington, D. C.

Oregon was also fortunate in that it only had two directors in its seven year history, unlike many state programs which played revolving doors with their directors. Alfred Powers, the Oregon Writers' Project first director, was enthusiastic, but as a part-time director, lacked the time and proper administrative skills to run the project efficiently and effectively. This lack of skills and problems with staff relations precipitated the major crisis of the Oregon Writers' Project, a threatened strike. After mediation, Powers was forced to resign and T. J. Edmonds was hired to replace him. It is interesting to note that this whole crisis was played out in just one week. The fact that such a major crisis could unfold and be resolved so quickly demonstrated the overall strength of the program in handling internal problems in an expedient and efficient manner. 
T. J. Edmonds, Powers' replacement, was a much more successful administrator than Powers. He was perhaps the epitome of the ideal director. Edmonds was credited for running a smoothly operating and harmonious staff, dealt well with supervisors, showed strong political skills in handling various agencies, and even had time to work as a troubleshooter in Washington state and northern California when their projects faltered.

But one of the major faults of both Powers and Edmonds was that both men allowed the Project to become side-tracked on numerous smaller publications, partially delaying publication of the Oregon Guide. If one considers that the Guide was the single major writing goal of the Oregon Project and that other states finished their guide in one to two years, Oregon must be severely criticized for the excessive amount of time, four years, taken to complete the work.

Ironically, this occurred partially because of the extreme popular and political support of the project in Oregon. Much of this enthusiasm was generated by Alfred Powers, who had numerous political and social contacts around the state. Other states, suffering from crippling political problems, likely relished the broad based support Oregon's program had. Yet, a price had to be paid for this support. The project under both directors suffered from allowing project members to spend time writing unauthorized publications which amounted to little more than Chamber of Commerce tracts and pro-0regon ballyhooism for special interest groups, towns and state and local agencies. These publications, because of their nature were safe politically but were at best of mediocre literary quality. T. J. Edmonds was equally as 
guilty as Powers in permitting this type of activity, even though he claimed to dislike it. In fact, Edmonds spent the last two years of the project having it function as little more than a propaganda arm for the war effort. During that period of time the writers failed to complete hardiy any of their other projects.

Washington at times chided Oregon for its practice of preparing non-guide publications. Yet, twice it followed Oregon's lead by authorizing such activities nationally. Recognizing that guide activities were not enough, the national office encouraged all states to take on supplemental publications in 1938. Two years later, it encouraged the states to work on war propaganda, citing Oregon's lead in this area. Such work, while perhaps necessary to keep writers active, did prevent Oregon from a speedier completion of its guide. The major administrative problem of the project and the major trouble spot of the program was the poor relations between the national editors in Washington, D.C. and the writers in Oregon. This study has illustrated the painful and lengthly process by which the guide was edited. In many cases Oregon was at fault in using poor writers, verbose or prosaic style, inaccurate or incomplete materials, and creating delays in sending copy to Washington. The national editors, on the other hand, could be equally faulted for constantly changing guidelines, delays in editing materials so that they became outdated, confusing instructions and a general insensitivity and snobbishness towards the Oregon writers. 
The problems between the two groups were one of the major failures of the project as a whole. Both sides failed to work out a smooth and efficient system for communications and for working together on the guide. The Washington office was too removed and too busy to be effective for the Oregonians. What was needed was a more regionalized editorial staff, conversant on the subject of Oregon and convenient to the Oregon staff. Edmonds proposed such a center be established in Salt Lake, Utah, but nothing ever came of the idea.

Despite these problems in editing the guide, it is interesting to note that many people who worked with the project in Oregon, including the two directors of the project, expressed general praise for the national editor's strict and exacting standards. These people, while not always happy with the severity and pettiness of the criticisms, felt that the quality of the work produced in Oregon was much higher because of the national editors. In essence, a strong love-hate relationship existed in Oregon for the Washington editors. Oregon writers resented the frequent interference, but in the long run they recognized, as writers, that their work was stronger for the criticism.

In assessing the written material of the Oregon Writers' Project, one may give the writers credit for being a fairly prolific group. In seven years, the writers produced numerous pamphlets, small histories and guides, radio shows, news articles and two major guidebooks. In addition three larger works, The Dictionary of Oregon History, Willamette Landings, and The History of Milwaukie, Oregon were published after the project's closure. 
Being prolific does not mean one is providing good quality. Frequently Oregon's written work suffered from questionable literary style and was affected by provincialism. The major guides, of course, were edited by Washington to measure up to strict standards, but most of the other materials, written to please local boosters, would have had difficulty meeting most critically accepted standards for good writing.

Today most of the published work, including the guidebooks, are dated and serve littie useful purpose. If one were to measure the lasting written accomplishments of the project, one would have to judge that aspect of the program a failure. As noted previously, the national office attempted to avoid controversy by selecting guide books and the likes for project activities. This not only encouraged mediocrity in writing, but also ensured that the works of the project, contrary to much publicity of the time, would have little lasting appeal.

The most significant accomplishment of the Writers' Project, including Oregon's, remains buried. In the Oregon State Archives in Salem, are numerous records, research notes, and interviews of Oregon's pioneers, depression victims, and average citizens of the day. This material, filled with the reminiscences of many now-deceased Oregonians, was one of the first large-scale attempts of folk and oral history. If this material were collected and edited, it could prove to be of greater and more lasting value than all the other published works of the project. Willamette Landings, a history of the riverboat industry on that river, edited after the Project's demise by Howard McKinley Corning, provides an example of how this material could be put to use. 
No price can be placed on this saved Oregonian history. That the collected research materials of the project have not been used more frequently is intriguing.

This study in surveying Oregon's involvement in the Federal Writers' Project has been especially sensitive to Ronald Taber's criticism of the project in the Pacific Northwest. As noted in the beginning of this work, Taber concluded his study of the Washington, Idaho, and Oregon projects by arguing that it could not be justified in those three states. While agreeing with Taber, that the Writers' Project was not a complete success, this study would have to differ with Taber by arguing that the project was justified in Oregon.

True, Idaho's project was almost a one person program and the Washington state project was a political hot potato, but in writing off the entire Pacific Northwest Taber neglects the relative success of the program in Oregon. Numerous unemployed white collar workers were employed in their chosen field. Administratively Powers created enthusiasm for the program that most other states would have relished and T. J. Edmonds proved to be a highly competent director effective not only in Oregon but elsewhere in the west. In terms of materials, Oregon published significant amounts, and left an even larger source of materials for the use of future historians.

Certainly there were significant failures of the project. Powers embarrassed the project with his lack of attention to it and personal involvement with a staff member, editing of written works was painful and inefficient, and the choice of innocuous writing materials left Oregon susceptible to writing mediocre tracts which are now dated. 
These projects served not as an example of the project's failure, but as problems occurring in the inherent weakness of the program. A future project of this sort would need to look at these failures and come to grips with them before they could function more smoothiy. This study would have to conclude that the Oregon Writers' Project as temporary employment for the unemployed writers, was a qualified success, was justified in its existence, and both its strengths and weaknesses could serve as an example for future endeavors of its type.

While the Oregon Writers' Project can be used to demonstrate the program's qualified success in helping unemployed writers, it is more difficult to use the project to test its effectiveness as governmental support of the arts. Unlike the music, art, or theater projects, little pretense was made by the administrators of the Federal Writers' Project that they were supporting direct artistic endeavors. The Federal Writers' Project was a practical experiment based on the given economic and political realities of the day. Those New Dealers who sponsored the project and those Washington administrators who ran the project sought nothing more than to put some unemployed writers to work preparing a series of guide books. In this they were successful. None of these people expected greatness to come of the project and few of them expected the written work to reach a state of artistic achievement.

One local participant of the program, Howard McKinley Corning, had his writing skilis preserved and enhanced through the project. He was one person who would argue that the program moved beyond the 
real and practical goals and actually created art. In responding to H. L. Davis' criticisms of the minute collecting aspects of the project, Corning wrote:

Art is conceivably everywhere, in everything, certainly in humanity in all of its expressions; it is the artists' challenge to invoke and evoke that art and its meaning; to make it live in whatever forms of expression he can command. Can't the dąy by day records of school room life be. . meaningful.

Few would concur with Corning that the work of the Writers' Project actually created art, but some would suggest, as Alfred Kazin did in On Native Ground, that the Writers' Project gave impetus to a new nationalism in American literature. ${ }^{4}$

In reality, however, as was demonstrated in Oregon, the Federal Writers' Project tried to discourage the freedom and flexibility which would have provided a climate for the writer to individually flourish in the artistic sense or to create a new literary movement. Those people who ran the Project shrewdly recognized from its inception that, where the writer was concerned, the government could not freely subsidize the arts without creating a sharp political outcry. The Federal Writers'. Project was not used to support art, but the unemployed writer. Where art was achieved within the strict parameters of the Project, the program administrators were delighted, but that was not the major goal of the program. True government subsidization of art did not occur in this program. The government did not give money directly to the writer to create as he/she professionally saw fit, but paid for services rendered on government directed and censored publications. 
If this project demonstrated anything about government support of art, it is that the Franklin Roosevelt administration refused to risk direct subsidization of the written art form. The project never really attempted to provide an answer as to the role of the government and the writer. It, instead; merely attempted to put writers to work in the least politically troublesome way possible during a period of severe depression.

In the long run the greatest achievement of the Writers' Project was not a series of guide books, proof that white collar relief was practical, or whether or not art had been created. The success of the project was the preservation and/or development of the writing skills of thousands of American men and women in a time of economic chaos. It is said that the greatness of a nation is measured by the greatness of its authors. We offer a debt of gratitude for the project each time we read a short story by John Cheever or Arna Bontemps, a poem by Weldon Kees or Margaret Waller, the histories of Studs Terkel, or a novel by Saul Bellow or Richard Wright. The significance of the project moves even beyond these few names of the great literary figures of the past few decades to include those thousands of faceless names of writers who never achieved any national distinction. They are the Claire Churchills, the Vern Brights, the Howard Mckinley Cornings and all the other members of the Oregon Writers' Project who were helped by this program. In turn, through their jobs as teachers, newspaperpersons, and participants of the Oregon literary scene, they have contributed to the art of the written word since the end of the project. 


\section{FOOTNOTES}

1. Ronald Taber, "The Federal Writers' Project in the Pacific Northwest: A Case Study" (Ph.D. dissertation, Washington State University, 1968 ), p. 93.

2. Ibid., p. 29 .

3. Howard McKinley Corning, "All the Words on the Page, I: H. L. David," Oregon Historical Quarterly, XXIII No. 4 (December, 1972), pp. 312-13.

4. Alfred Kazin, On Native Ground: An Interpretation of Modern American Prose Literature (New York, 1942), pp. 501-503. 


\section{A SELECTED BIBL IOGRAPHY}

\section{Manuscript Collections}

This study was based largely upon the administrative records of the Oregon Writers' Project. It was originally believed that the original copies of these records were held by the Oregon Historical Society (Portland, Oregon). The present author was allowed access to these unsorted and unprocessed materials and discovered that the bulk of the materials included in the files were actually misplaced records of a lumber company. Because of this the primary manuscript source was the duplicate of the original records which are deposited in Record Group 69: central correspondence files of the Works Project Administration, Records of the Federal Writers Project, National Archives (Washington, D.C.). The specific citations for collections used from that record group are given under "Public Documents" in this bibliography.

The Oregon State Archives (Salem, Oregon) has the major collection of Oregon Writers' Project material in the state. There are no administrative files in this collection but there are historical notes on counties, folklore material and biographies, and interviews of Oregonians. Some additional materials from several counties can also be found in the Special Collections Division of the University of Oregon Library (Eugene, Oregon).

\section{Public Documents}

Oregon State Archives. Records of the Works Project Administration related to the Oregon Federal Writers; Project. Salem, Oregon: 1935-1941.

State of Oregon. Oregon Laws, 1937. Salem, Oregon: Public Printer, 1937.

U. S. National Archives and Records Service Records of the Federal Writers' Project Relating to Henry G. Alsberg and George W. Cronyn, 1935-1939. Record Group 69: Central correspondence files of the Works Projects Administration. Washington, D.C.: General Services Administration, 1968. (Microfilmed.) 
: Records Relating to the WPA Writers' Project in Oregon, 1935-42 Record Group 69: Central correspondence files of the Works Projects Administration--State Series. Washington, D.C.: General Services Administration, 1968. (Microfilmed)

\section{Newspapers}

Oregonian (Portland, Oregon), 1935-1942.

Oregon Journal (Portland, Oregon), 1935-1942.

\section{Books}

Alsberg, Henry G. (ed.). The American Guide. New York: Hastings, 1949.

Bendiner, Robert. Just Around the Corner: A Highly Selective History of the Thirties. New York: Dutton, 1968.

Bernstein, Barton J. (ed.). Towards a New Past: Dissenting Essays in American History. New York: Random House, 1969.

- Twentieth Century America: Recent Interpretation. New York: Harcourt, Brace and World, 1969.

Bernstein, Irving. The Lean Years: A History of the American Worker, 1920-1933. Baltimore, Maryland: Penguin Books, 1966.

Charles, Seatle F. Minister of Relief: Harry Hopkins and the Depression. Syracuse, New York: Syracuse University Press, 1963.

Conkin, Paul K. The New Deal. New York: Thomas Y. Crowell Company, 1967.

Corning, Howard McKinley (ed.). Dictionary of Oregon History. Portland, Oregon: Binfords and Mort, 1956.

- Willamette Landings. Portland, Oregon: Glassnel Dahistrom, $194 \overline{1 .}$

Degler, Carl N. Out of Our Past: The Forces that Shaped Modern America New York: Harper \& Row, 1959.

Freidel, Frank (ed.). The New Deal and the American People. Englewood Cliffs, N.J.: Prentice-Hall, 1964.

Gilbert, James Burkhart. Writers and Partisan: A History of Literary Radicalism in America. New York: John Wiley and Sons, Inc., 1968. 
Gurko, Leo, The Angry Decade. New York: Dodd, Meal, 1946.

Howard, Donald W. The WPA and Federal Relief Policy. New York: Russell Sage Foundation, 1943.

Ickes, Harold L. The Secret Diary of Harold I. Ickes, I: The First Thousand Days, 1933-1936. New York: Simon and Schuster; 1954.

Kazin, Alfred. On Native Grounds: An Interpretation of Modern American Prose Literature. New York: Reynal and Hitchcock, 1942.

Leuchtenberg, William E. Franklin D. Roosevelt and the New Deal: 1932-1940. New York: Harper \& Row, 1963.

Macmahon, Arthur W., John D. Millett and Gladys Ogden. The Administration of Federal Work Relief. Chicago: Public Administration Service, 1941.

Mangione, Jerre. The Dream and the Deal: The Federal Writers' Project, 1935-1943. Boston: Little, Brown and Company, 1972.

McDonald, William F. Federal Relief Administration and the Arts. Columbus, Ohio: Ohio State University Press, 1969.

Miller, James E., Jr. (ed.). The Arts and the Public. Chicago: University of Chicago Press, 1967.

01son, Charles 0laf. History of Milwaukie, Oregon. Milwaukie, Oregon: Milwaukie Historical Society, 1965.

Powers, Alfred. History of Oregon Literature. Portland, Oregon: Metropolitan Press, 1935.

Rosenman, Samuel (ed.). The Public Papers and Addresses of Frankl in D. Roosevelt. 13 vols. New York: Random House, 1938-1950.

Schlesinger, Arthur M., Jr. The Age of Roosevelt. 3 vols. New York: Houghton Mifflin, 1957-1960.

Swados, Harved (ed.). The American Writer and the Great Depression Indianapolis, Indiana: The Bobbs-Merrill Co., 1966.

Taber, Ronald Warren. "The Federal Writers' Project in the Pacific Northwest: A Case Study." Ph.D. dissertation, Washington State University, 1969.

Workers of the Writers' Program of the Works Project Administration in the State of Oregon. Mount Hood: A Guide. New York: Duel, Sloan and Pearce, 1940. 
- Oregon: End of the Trail. Portland, Oregon: Binfords and Mort, 1940.

\section{Articles and Periodicals}

"Alsberg Dismissed as Head of Writers' Project." The Publishers' Week ly, CXXXVI (Aug. 19, 1939), 513.

Alsberg, Henry G. "Writers and the Government: A Letter from the Director of the Federal Writers' Projects." The Saturday Review of Literature, XIII (Jan. 4, 1936), 9.

Bendiner, Robert. "When Culture Came to Main Street." Saturday Review, L (Apri1 1, 1967), 19.

Billington, Ray Allen. "Government and the Arts: The W.P.A. Experience," American Quarterly, XIII (Winter, 1961), 466.

Bolles, Blair. "The Federal Writers' Project." The Saturday Review of Literature. XVIII (JuTy 9, 1938), 3.

Cantwell, Robert. "America and the Writers' Project." The New Republic, IIC (April 26, 1939), 323.

Colby, Merle. "Presenting America to All Americans." The Publishers' Week ly, CXXXIX (May 3, 1941), 1828.

"Completion of American Guide Series." The Publishers' Weekly, CXXXIX (May 3, 1941), 1815.

Corning, Howard McKinley. "All the Words on the Page, I: H. L. Davis," Oregon Historical Quarterly, LXXIII, No. 4 (December, 1972), 312.

DeVoto, Bernard. "The First WPA Guide." The Saturday Review of Literature, XV (Feb. 27, 1937), 8. "The Writers' Project." Harper's Magazine, CLXXXIV (Jan., $1942), 221$.

"Distributing the WPA Guides." The Publishers' Weekly, CXXXVII (May 11, $1940), 1836$.

Fox, Daniel. "Archives of the Federal Writers." American Quarterly, XIII (Spring, 1961), 3.

Horlings, Albert. "Guidebooks to America." The New Republic, CVI (April 13, 1942), 501. 
Kellock, Katharine. "The WPA Writers: Portraitists of the United States." The American Scholarly, IX (Oct., 1940), 473.

"Killing The Writers' Project." The New Republic, C (Aug. 23, 1939), 62.

"Mirror of America." Time, XXXI (Jan. 3, 1938), 55.

Mumford, Lewis. "A letter to the President." The New Republic, LXXXIX (Dec. 30, 1936), 263.

"Writers' Project." The New Republic, LXXXII (0ct. 20, 1937), 306.

Netboy, Anthony. "Letters to the Editor." Saturday Review, L (April 29, $1967), 23$.

"Publishers' Letter on Federal Writers' Project." The Publishers' Week ly. CXXV (May 20, 1939), 1817.

Putnam, Jared. "Guides to America." Nation, CIIIL (Dec. 24, 1938), 694.

"The Shape of Things." The Nation, CIL (Aug. 19, 1939), 182.

Touhey, Eleanor. "The American Baedekers." Library Journal, CXVI (April 15, 1941), 339.

Ulrich, Mabel S. "Salvaging Culture for the WPA." Harper's Magazine. CLXXVIII (May, 1939), 653.

"What the Writers Wrote." The New Republic, LXXXXII (Sept. 1, 1937), 89.

"Work of the Federal Writers' Project of WPA." The Publishers' Weekly. CXXXV (March 18, 1939), 1130.

"WPAccounting." Time, XXXXI (Feb. 15, 1943), 96.

"WPAchievement." Time, XXXV (Aug. 12, 1940), 64.

"Writers' Project: 1942." The New Republic, CVI (April 13, 1942), 480.

\section{Interviews}

Corning, Howard McKinley, Portland, Oregon, April 6, 1973.

Everett, Gladys, Portland, Oregon, June 4, 1973.

Powers, Alfred, Portl and, Oregon, June 7, 1973. 